Article

\title{
Zero-Tillage Effects on Durum Wheat Productivity and Soil-Related Variables in Future Climate Scenarios: A Modeling Analysis
}

\author{
Àngela Puig-Sirera 1,*(D), Marco Acutis ${ }^{2}\left(\mathbb{D}\right.$, Marialaura Bancheri ${ }^{1}$, Antonello Bonfante ${ }^{1}$, Marco Botta ${ }^{2}$, \\ Roberto De Mascellis ${ }^{1}$ (D), Nadia Orefice ${ }^{1}$, Alessia Perego ${ }^{2} \mathbb{D}$, Mario Russo ${ }^{3}$, Anna Tedeschi ${ }^{4}$ (D) , Antonio Troccoli ${ }^{3}$ \\ and Angelo Basile ${ }^{1}$ (D)
}

1 Institute for Mediterranean Agricultural and Forestry Systems, National Research Council, P. le Enrico Fermi 1, 80055 Portici, Italy; marialaura.bancheri@isafom.cnr.it (M.B.); antonello.bonfante@cnr.it (A.B.); roberto.demascellis@cnr.it (R.D.M.); nadia.orefice@cnr.it (N.O.); angelo.basile@cnr.it (A.B.)

2 Department of Agricultural and Environmental Sciences-Production, Landscape, Agroenergy, University of Milan, Via G. Celoria 2, 20133 Milan, Italy; marco.acutis@unimi.it (M.A.); marco.botta@unimi.it (M.B.); alessia.perego@unimi.it (A.P.)

3 Cereal Research Centre, Council for Agricultural Research and Economics, 71122 Foggia, Italy; mario.russo@crea.gov.it (M.R.); antonio.troccoli@entecra.it (A.T.)

4 Research Division Portici, Institute of Biosciences and Bioresources (IBBR), National Research Council of Italy (CNR), Via Università 133, 80055 Portici, Italy; anna.tedeschi@cnr.it

* Correspondence: angela.puig@isafom.cnr.it; Tel.: +39-338-4306271

\section{check for}

Citation: Puig-Sirera, À.; Acutis, M.; Bancheri, M.; Bonfante, A.; Botta, M.; De Mascellis, R.; Orefice, N.; Perego, A.; Russo, M.; Tedeschi, A.; et al. Zero-Tillage Effects on Durum Wheat Productivity and Soil-Related Variables in Future Climate Scenarios: A Modeling Analysis. Agronomy 2022, 12, 331. https://doi.org/10.3390/ agronomy12020331

Academic Editor: Aiming Qi

Received: 22 December 2021

Accepted: 26 January 2022

Published: 27 January 2022

Publisher's Note: MDPI stays neutral with regard to jurisdictional claims in published maps and institutional affiliations.

Copyright: (C) 2022 by the authors. Licensee MDPI, Basel, Switzerland. This article is an open access article distributed under the terms and conditions of the Creative Commons Attribution (CC BY) license (https:// creativecommons.org/licenses/by/ $4.0 /)$.

\begin{abstract}
Adoption of zero-tillage practices with residue retention in field crops has been introduced as an alternative soil-management technique to counteract the resource degradation and high production costs derived from intensive tillage. In this sense, the biophysical models are valuable tools to evaluate and design the most suitable soil-management technique in view of future climate variability. The aim of this study was to use the ARMOSA process-based crop model to perform an assessment of tillage (T) and no-tillage (No-T) practices of durum-wheat-cropping systems in the Campania region (South of Italy) under current and future climate scenarios. First, the model was calibrated using measurements of soil water content at different depths, leaf area index, and aboveground biomass in the $\mathrm{T}$ and No-T treatments during the 2013-2014 season. Then, the model was further applied in the $\mathrm{T}$ and No-T treatments to future climate data for 2020-2100 that was generated by the COSMO-CLM model using the RCP4.5 and 8.5 paths. Results of the calibration depicted that the model can accurately simulate the soil-crop-related variables of both soil-management treatments, and thus can be applied to identify the most appropriate conservation agricultural practices in the durum-wheat system. The simulation of soil water content at different depths resulted in small relative root mean square errors (RRMSE $<15 \%$ ) and an acceptable Pearson's correlation coefficient ( $r>0.51$ ); and the goodness-of-fit indicators for simulated LAI and AGB resulted in acceptable RRMSE (RRMSE $<28 \%$ ), and high $r(r>0.84)$ in both soil-management treatments. Future climate simulations showed that No-T management will deliver $10 \%$ more wheat yield than the $\mathrm{T}$, with an annual average $0.31 \%$ year $^{-1}$ increase of soil organic carbon, and an increase of $3.80 \%$ year $^{-1}$ for $\mathrm{N}$ uptake, which can diminish the $\mathrm{N}$ leaching. These results suggest that No-T could be implemented as a more resilient management for farming system in view of climate uncertainty and scarcity of resources. Therefore, these findings support the potential of the ARMOSA model to evaluate the soil-crop response of the durum-wheat system under different management conditions and to design appropriate soil-management practices for current and future climate predictions.
\end{abstract}

Keywords: climate change; conservation agriculture; crop-based model; durum wheat; soil spatial variability 


\section{Introduction}

The degradation of land and ecosystem services caused by intensive tillage agricultural practices has prompted an alternative farming paradigm known as conservation agriculture [1].

Conservation agriculture (CA) is an aggregate of best management practices that is built on three linked principles: minimum soil disturbance (i.e., no-tillage; No-T), preservation of a permanent soil organic cover, and crop rotation and diversification [2]. These practices are meant to counteract soil degradation and enhance microbial biomass and water infiltration by minimum tillage. Meanwhile, mulching could diminish soil evaporation and runoff, enhance topsoil organic matter, and improve the stability of surface soil aggregates [3-6]. Moreover, No-T practices reduce production costs by decreasing fuel consumption and thus, greenhouse emissions $[1,7]$.

Consequently, all these practices should sustain and increase crop productivity, and water and nutrient use efficiency, which would be translated into raising the farmer's income. However, there is still the belief among farmers that CA practices can cause yield penalties, which is preventing their adoption and spread [1,8,9]. Moreover, it is important to bear in mind that the benefits of CA previously stated may not be visible in the short term, but rather in the medium- and long-term results $[7,9]$. In addition, much research has been carried out about the effects derived from converting to CA, which highlighted diverse responses according to local characteristics. Thus, the overall outcomes demonstrated the need to design site-specific soil-management practices to translate their potential into environmental and economic benefits [7].

The CA farming system has grown in recent years at a global scale, with CA cropland representing $12.5 \%$ of the total global cropland in 2016, with an increased tendency. Specifically, CA was implemented in $45 \%$ and $32 \%$ of the total cropland in USA and South America, respectively [1]. In addition, although the Common Agricultural Policy of the European Union (CAP, Rural Development Programme 2014-2020) promoted the adoption of CA, there has not been a sustained and broad adoption of these practices in European agriculture, and CA farmland represents only $5 \%$ of the EU's total cropland [1]. Specifically, in the case of Italy, the part of arable land that farmers declared would be dedicated to No-T practices represent around $6 \%$ of the total Utilized Agricultural Area, according to the last available agriculture census [10], which has been grant-supported by the rural development programmes of the Italian administrative regions [11]. Therefore, these agricultural practices are still in a developing phase in Italy, with constraints for implementation in a lack of know-how and the mindset that CA would lead to yield penalties [9].

The future CAP (2023-2027) has listed CA as an agricultural practice supported by the new so-called eco-scheme instrument, as these practices foster climate mitigation and prevent soil degradation. Therefore, farmers that promise to implement $\mathrm{CA}$ in their cultivation practices will be rewarded by this new instrument of the CAP policy [12].

The durum-wheat crop cultivated in the Campania region represents $4.4 \%$ of the national surface (i.e., 1.21 million ha) and $4.5 \%$ of the national production $\left(4.2 \times 10^{6} \mathrm{~kg}\right)$ [10] In the Campania territory there are three main milling industries, which represent $3 \%$ of the total national industries, with a producing capacity of more than $2 \times 10^{5} \mathrm{~kg}$; and 15 pasta industries, which represent $13 \%$ of total national production. In Italy, semolina production reached $4.2 \times 10^{6} \mathrm{~kg}$ in 2020 (an increase of 9\% compared to 2019) and $3.85 \times 10^{6} \mathrm{~kg}$ were used for pasta making [13].

Italy is the second highest-producing country in the world of durum wheat $\left(4.2 \times 10^{6} \mathrm{~kg}\right)$, after Canada $\left(5.2 \times 10^{6} \mathrm{~kg}\right)$; and the first in Europe, which accounts for $49.4 \%\left(8.5 \times 10^{6} \mathrm{~kg}\right)$ of the total EU production [14]. Among the Italian regions, Puglia (25.2\% of the total national production) represents the top producer, reaching about one million tons, while Campania is listed in the eighth place [10].

In the Campania region, the most common method for wheat cultivation is by conventional tillage (T), while direct seeding is barely spread and is decreasing [9]. The impact of $\mathrm{T}$ is especially considerable in terms of energy and environmental factors in the hilly 
and mountainous areas of Campania because they predispose the land to water and wind erosion, that lead to a loss of fertility in cultivated land.

An increase in the severity and frequency of drought and floods events, changes in precipitation, temperature, and the carbon dioxide concentration in the atmosphere have been forecast for the Mediterranean region [15-17]. This variability in the climate is predicted to have effects on soil water availability, carbon storage, and in crop yields and quality. Consequently, it is paramount to study farm management strategies that maintain agricultural production at environmental and economically viable levels. Among these strategies, CA is being fostered as valuable mitigation and adaptation practices to environmental changes that are affecting farming systems [7,18,19]. Farmers have been able to adopt CA strategies in different agri-environmental characteristics to cope with climate variability [20].

Field tillage experiments are time-consuming, expensive, laborious, and require specific expertise skills. Thus, properly calibrated crop process-based models may be used to evaluate the impact of diverse soil-management techniques on crop productivity and water-nutrients dynamics to identify the most appropriate and site-specific soil-management strategies [1,6,21]

Some studies have employed crop-based models to evaluate the effects of different CA practices on crop performance, soil-water balance, and nutrients dynamics under different agro-environmental conditions [19,22-24]. However, these studies showed that most of the available crop models are not able to simulate accurately the long-term effects of the differences between CA and T [25]. Authors argue that this fact may be due to missing specific modules (i.e., a tillage module) in the models to depict the effects of CA operations on soil variables [4]; and flexibility in defining farm management practices that change season by season [25].

Process-based crop modeling has been coupled with weather projections to gain knowledge on the effects of climate change on agricultural production, and thus identify the most appropriate CA strategies [20]. In this way, crop modeling could provide insight on mitigations and adaptations to climate change by recognizing proper conservation agricultural practices [26].

The ARMOSA model is a process-based cropping system model that has been proved to be suitable for field crops and to simulate different soil-management practices under diverse environmental conditions $[7,27,28]$.

The overall objective of the study was to evaluate the effect of two different soilmanagement practices- $\mathrm{T}$ and No-T-on durum-wheat productivity and soil-related variables in the Mediterranean climate in current and future scenarios by using the ARMOSA model (Figure 1).

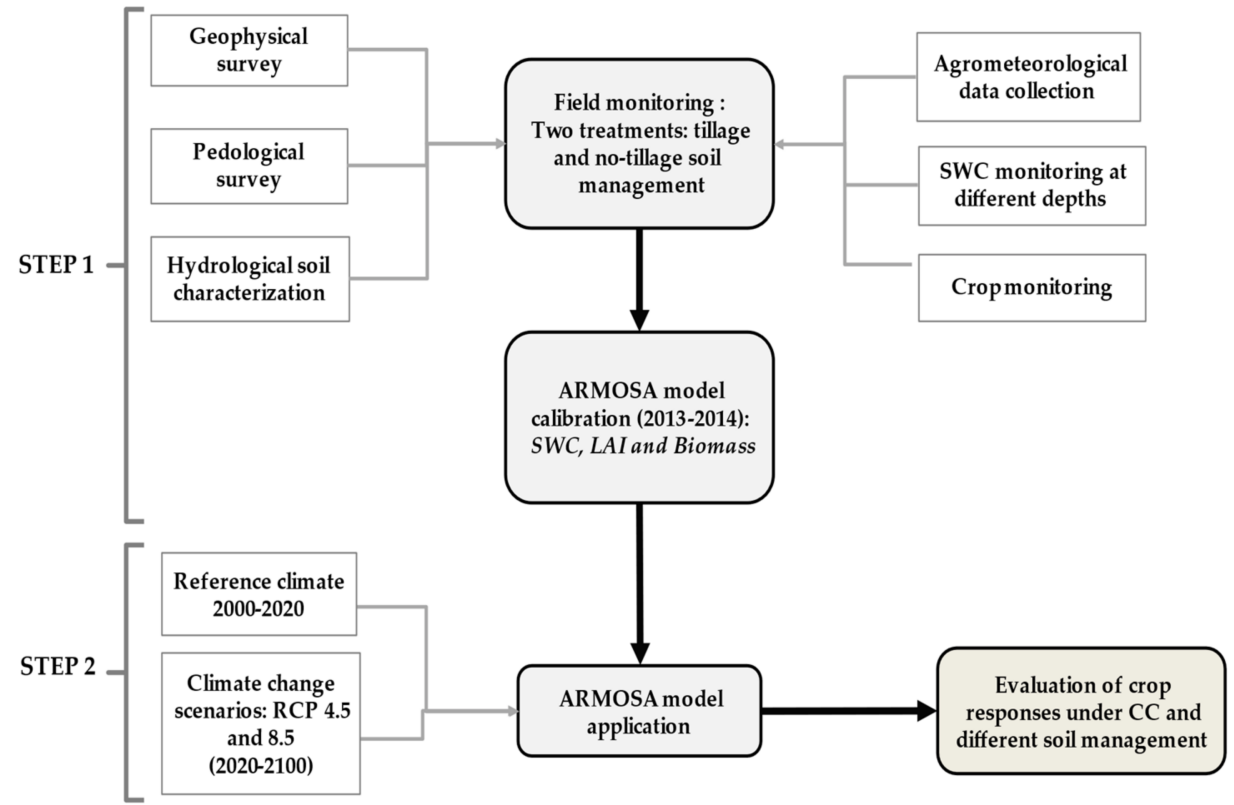

Figure 1. Storyline of the methodology applied. 
The specific objectives consisted of (i) calibration of the parameters of the crop growth model for durum wheat under $\mathrm{T}$ and No-T soil-management techniques in a hilly Mediterranean region; and (ii) forecast wheat productivity, soil organic carbon (SOC) stock, and nitrogen $(\mathrm{N})$ uptake under two contrasting climate-change scenarios for $\mathrm{T}$ and No-T soil management.

\section{Materials and Methods}

\subsection{Site Description}

The field data acquisition was conducted during the period 2013-2014 (October-June) in the durum-wheat field located in Scampitella (Campania, Italy $535 \mathrm{~m}$ a.s.l.). The durumwheat field (Triticum durum Desf., var. Iride) covers 8.5 ha with a crop density of 350 viable seeds per $\mathrm{m}^{-2}$. The selected farm is a representative durum-wheat farm in the Campania region in terms of farm size, economical dimensions, and agronomic and soil-management practices [10].

The experimental area was located in two sites, with different soil-management strategies, which were used for field monitoring. The T treatment (1.5 ha; $41^{\circ} 08^{\prime} 77^{\prime \prime} \mathrm{N}$, $15^{\circ} 33^{\prime} 80^{\prime \prime} \mathrm{E}$ ) involved ploughing in summer at $40 \mathrm{~cm}$ depth using a subsoiler, and in autumn at least two secondaries tillage using a disk harrow for seedbed preparation. The No-T management (No-T) $\left(7.0\right.$ ha; $\left.41^{\circ} 08^{\prime} 59^{\prime \prime} \mathrm{N}, 15^{\circ} 33^{\prime} 79^{\prime \prime} \mathrm{E}\right)$ started in the 2008-2009 growing season. A non-selective herbicide treatment was used (i.e., glyphosate at $3 \mathrm{~L} \mathrm{ha}^{-1}$ ) for weed control, and after 7-10 days the durum wheat was sown with a specific seeder "Directa" 300 (:MASCHIO GASPARDO S.p.A., Campodarsego, PD, Italy) for undisturbed soil.

Before sowing and for both treatments, the basal fertilization was $36 \mathrm{~kg} \mathrm{~N} \mathrm{ha}^{-1}$ and 42.24 $\mathrm{P} \mathrm{ha}^{-1}$ (200 $\mathrm{kg} \mathrm{ha}^{-1}$ of di-ammonium phosphate, DAP, 18-46-00), while during the initial tillering and stem-elongation stages of the durum wheat, $46 \mathrm{~kg} \mathrm{~N} \mathrm{ha}^{-1}\left(100 \mathrm{~kg} \mathrm{ha}^{-1}\right.$ of urea 46-00-00) and $42 \mathrm{~kg} \mathrm{~N} \mathrm{ha}^{-1}$ (200 kg ha ${ }^{-1}$ of sulfate of ammonia, SOA, 21-00-00) were applied, respectively. In both techniques, the management of crop residues was envisaged. The latter were chopped directly in the field by the combine harvester during harvesting (21 June 2014) and buried in the T treatment with ploughing and kept on the surface in the No-T treatment.

The climate is typically Mediterranean, with annual rainfall varying between 600 and $1000 \mathrm{~mm}$, most of which falls in fall and winter; average monthly temperatures vary from $7^{\circ} \mathrm{C}$ to $27^{\circ} \mathrm{C}$, respectively, from January to July (Figure 2).

\subsection{Soil Characterization}

A geophysical scan of the farm soils using the electromagnetic induction (EMI) (GSSI: Nashua, NH, USA) sensor was performed to investigate the spatial variability of the field experimental farm. The EMI sensor allowed us to obtain aggregated information on the spatial variability of soils through the volumetric measure of the apparent electrical conductivity of soils.

The Profiler EMP-400 conductivity meter (GSSI: Nashua, NH, USA) was used to assess the soil's apparent electrical conductivity. The Profiler used three frequencies at 5, 10, and $15 \mathrm{KHz}$ in vertical dipole mode (VDM). The Tx and Rx coils were spaced $1.22 \mathrm{~m}$ apart with a depth of investigation of $1.95 \mathrm{~m}$. The instrumentation was placed on a PVC sled and was towed by a tractor placed at about $5 \mathrm{~m}$ to avoid interference phenomena and data alteration. The use of the sled maintains a constant distance of the instrument from the ground to perform the acquisition faster and more easily.

The data obtained were filtered to eliminate any outliers, and then were subjected to variographic analysis and interpolated by ordinary kriging.

The pedogenetic horizons recognized in the opening of the soil profiles were sampled for the chemical-physical and hydrological analyses in the two plots located in the $\mathrm{T}$ and No-T field, respectively. Chemical analyses were conducted according to the Official Methods for Soil Chemical Analysis developed by the Italian Ministry of Agriculture and Forestry Policies [30]. The soil organic matter was determined by oxidation with potassium 
dichromate solution in the presence of sulfuric acid following the Walkley-Black method. The $\mathrm{pH}$ values were determined in $\mathrm{H}_{2} \mathrm{O}$ (soil/water suspension 1:2.5) and in $\mathrm{KCl} 1 \mathrm{M}$ (soil suspension/solution 1:2.5). The CEC was determined according to the $\mathrm{BaCl} 2$ method at $\mathrm{pH}$ 8.2 and triethanolamine. The total carbonate content was determined by acid solubilization and gas-volumetric determination of $\mathrm{CO}_{2}$, which takes place by treating a fine soil sample with hydrochloric acid and measures with the Dietrich-Fruehling calcimeter. The electrical conductivity was determined on aqueous extract, with water-soil ratio of 5:1.
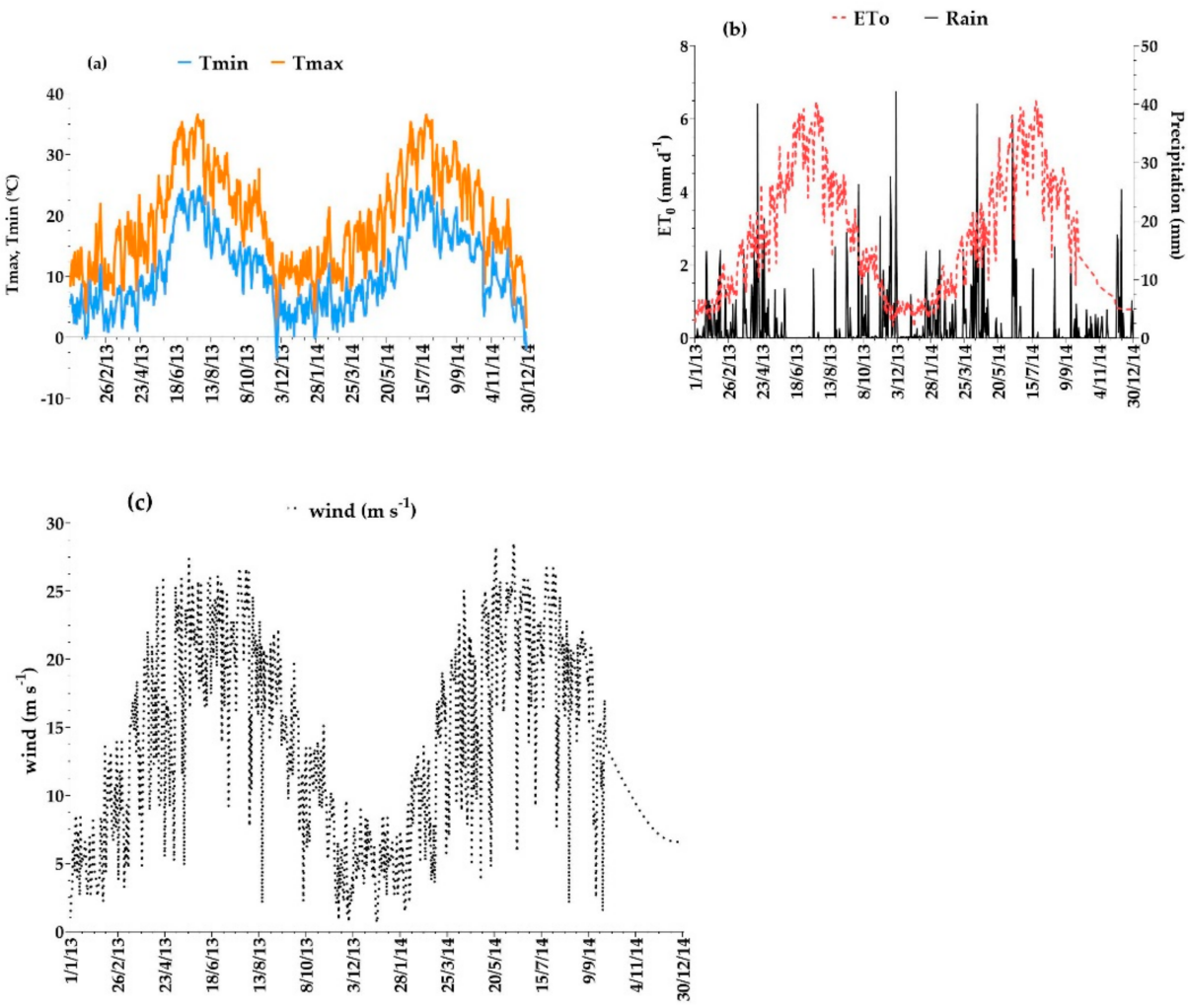

Figure 2. Daily acquired climatic variables at the weather station located in the experimental site in 2013 and 2014: (a) maximum $\left(\mathrm{T}_{\max }\right)$ and minimum $\left(\mathrm{T}_{\min }\right)$ temperatures, $(\mathbf{b})$ precipitation and Hargreaves-reference evapotranspiration $\left(\mathrm{ET}_{\mathrm{o}}\right)[29]$, and $(\mathrm{c})$ wind speed at $2 \mathrm{~m}$ height $\left(\mathrm{u}_{2}\right)$.

The soil texture was measured by a laser diffractometry granulometer (Malvern Mastersizer 2000:Malvern, UK).

The hydraulic properties were carried out by laboratory analyses on undisturbed samples taken in each of the soil horizons. First, soil samples were saturated, then (i) the saturated soil water content, $\theta$ s, was measured by a gravimetric method and (ii) the saturated hydraulic conductivity, ks, was measured using the falling head permeameter [31].

Subsequently, after inserting three tensiometers at different depths in the soil sample, an automatically recording of the pressure head and the weight of the sample during a 1-dimensional evaporation process, allowed us to get three $h(t)$ time series for the three different depths where the tensiometers were inserted and one averaged for the whole soil sample times series, $\theta(t)$ [32]. From this information the water retention curve was obtained by applying an iterative method [33]. Additional points of the dry branch of the water retention curve were determined using a dewpoint potentiometer (WP4-T, Decagon Devices, Washington, DC, USA). Finally, these water retention data were parameterized by fitting measured data to the van Genuchten model [34].

\subsection{Field Monitoring}

The dates defining the crop phenological stages and the corresponding $\mathrm{BBCH}$ decimal code for the growth stages of durum wheat, following the Zadocks scale [35], are indicated 
in Table 1 for the crop-growing season of the study. The planting date of the two fields took place on 26 October 2013 using the Iride cultivar of durum wheat, and the harvest date took place on the 21 June 2014 in both fields (i.e., 236 days after sowing, DAS).

Table 1. Days after sowing (DAS) and BBCH of the crop growth stages.

\begin{tabular}{|c|c|c|c|c|c|c|c|c|c|}
\hline \multicolumn{10}{|c|}{ Crop Growth Stages } \\
\hline Season & Sowing & Emergence & Tillering & $\begin{array}{c}\text { Stem } \\
\text { Elongation }\end{array}$ & $\begin{array}{c}\text { Ear } \\
\text { Emergence }\end{array}$ & Flowering & $\begin{array}{l}\text { Begin Grain } \\
\text { Filling }\end{array}$ & $\begin{array}{c}\text { Physiological } \\
\text { Maturity }\end{array}$ & Harvest \\
\hline 2013-2014 & 0 & 31 & 103 & 141 & 165 & 184 & 206 & 224 & 236 \\
\hline BBCH scale & 00 & 09 & 29 & 35 & 55 & 65 & 73 & 89 & 99 \\
\hline
\end{tabular}

Table 2 illustrates the several variables measured in the experimental field.

A weather station (Watchdog 2900ET_-Spectrum Technologies) was set up next to the experimental site for the hourly automatic acquisition of precipitation, air temperature at $2 \mathrm{~m}$ height, relative humidity, wind velocity, and solar radiation.

Plant biophysical characteristics (e.g., leaf area index, aboveground biomass) were measured starting from the tillering stage of wheat and up to harvest following the phenological stages indicated in Table 1 to characterize the response of the plant to the two cultivation methods.

Eight aboveground biomass samples were taken from an area of $0.51 \mathrm{~m}^{2}(1.02 \times 0.5 \mathrm{~m})$, which included six contiguous rows. The sampling at harvest was taken from an area of $1 \mathrm{~m}^{2}$ within each test area and used to measure the following parameters: height of the plant (cm, excluding awns), total weight of biomass and grain $\left(\mathrm{g} \mathrm{m}^{-2}\right)$, and harvest index (weight of grain/total weight of biomass $\times 100$ ).

The leaf area index (LAI) was measured by using LAI Licor 2000(LI-COR Inc.: Lincoln, NE, USA). Three random subareas of each experimental field were selected of $0.09 \mathrm{~m}^{2}$ $(0.3 \times 0.3 \mathrm{~m})$, for a total number of nine samples in each field.

Once the LAI measurements were completed, the plant material collected was used for the estimation of the aboveground biomass (AGB) by drying in an oven at $65^{\circ} \mathrm{C}$ until a constant weight was reached. Until 11 April, the plant material was mainly leaves. After this date, when stems and spikes were well-differentiated, the plant was separated into the different fractions. The total aboveground biomass was obtained by adding up the component fractions.

Rooting depth was measured on $7 / 2$, $18 / 3$ and $30 / 4 / 14$ by trenching in the soil. Subsequent excavations did not show substantial differences compared to the observation on $30 / 4$, therefore the measurements of the rooting depth were discontinued.

Three random test areas of $21 \mathrm{~m}^{2}$ each $(7.0 \times 3.0 \mathrm{~m})$ were selected in each field to measure at harvest the grain yield ( $\mathrm{kg} \mathrm{ha}^{-1}$ adjusted to $13.0 \%$ moisture).

Two automatic stations were set up for data acquisition of soil water content by using the time domain reflectometry (TDR) technique. The stations adopted consisted of a Campbell TDR100 time domain reflectometer, to which are connected, through a system of SDMX50SP Campbell coaxial multiplexers, 12 probes.

The TDR probes were installed at $0-15,20,30,40$, and $50 \mathrm{~cm}$ depth according to the recognized pedological horizons. The probes were self-built and calibrated to determine the exact length of the cable and the electrical length, thus the probes were of the threewire type with steel waveguides varying between $10 \mathrm{~cm}$ and $15 \mathrm{~cm}$ in length. The data acquisition and recording were carried out by a CR10X Campbell datalogger (Campbell Scientific: Logan, UT, USA). The waveforms were collected every $4 \mathrm{~h}$ starting from 18 November 2013 until 26 June 2014. 
Table 2. Field measured variables to be used in the model simulations.

\begin{tabular}{|c|c|c|c|c|c|}
\hline \multicolumn{6}{|c|}{ Field Monitoring } \\
\hline & Variable & Method & Frequency & $\begin{array}{c}\text { Number of } \\
\text { Measurements }\end{array}$ & Type \\
\hline \multirow[t]{2}{*}{ Meteorology } & $\begin{array}{c}\text { Minimum/maximum air } \\
\text { temperature }\left({ }^{\circ} \mathrm{C}\right) \\
\text { Relative humidity }(\%) \\
\text { Global solar radiation }\left(\mathrm{MJ} \mathrm{m}{ }^{-2}\right) \\
\text { Precipitation }(\mathrm{mm})\end{array}$ & $\begin{array}{l}\text { Local meteorological } \\
\text { station }\end{array}$ & Daily & 730 & Continuous \\
\hline & $\begin{array}{l}\text { Reference evapotranspiration } \\
(\mathrm{mm})\end{array}$ & $\begin{array}{l}\text { Hargreaves } \mathrm{ET}_{\mathrm{o}} \\
\text { method }\end{array}$ & Daily & 730 & Continuous \\
\hline Soil & $\begin{array}{l}\text { Volumetric soil water content } \\
\qquad\left(\mathrm{m}^{3} \mathrm{~m}^{-3}\right)\end{array}$ & $\begin{array}{l}\text { Time domain } \\
\text { reflectometry sensor }\end{array}$ & Daily & $\begin{array}{c}460(\mathrm{~T}) \\
548(\mathrm{No}-\mathrm{T})\end{array}$ & Continuous \\
\hline \multirow{2}{*}{ Crop } & Leaf area index $\left(\mathrm{m}^{2} \mathrm{~m}^{-2}\right)$ & LAI Licor 2000 & $\begin{array}{c}\text { At each } \\
\text { phenological stage }\end{array}$ & 6 & Discontinuous \\
\hline & Aboveground biomass $\left(\mathrm{Kg} \mathrm{ha}^{-1}\right)$ & Oven drying & $\begin{array}{c}\text { At each } \\
\text { phenological stage }\end{array}$ & 9 & Discontinuous \\
\hline
\end{tabular}

\subsection{Climate Scenarios}

Future climate scenarios were obtained by using the high-resolution regional climate model (RCM) COSMO-CLM [36] employing a spatial resolution of about $11 \mathrm{Km}$ at European level with optimization at Italian scale, able to employ a spatial resolution of $0.0715^{\circ}$ (about $8 \mathrm{~km}$ ). These last model data were validated, resulting in agreement with different regional high-resolution observational datasets, in terms of average temperature and precipitation [37] and in terms of extreme events [38].

In particular, two different simulations were performed by employing two standard IPCC (Intergovernmental Panel on Climate Change) RCP4.5 and RCP8.5 greenhouse gas (GHG) concentrations [39]. Specifically, the RCP4.5 scenario shows stabilization in the GHG emissions, while the RCP8.5 scenario has a rapid increase of the GHG concentration. The initial and boundary conditions for running RCM simulations with COSMO-CLM were provided by the general circulation model CMCC-CM [40], whose atmospheric component (ECHAM5) has a horizontal resolution of about $85 \mathrm{~km}$. For both future climate scenarios, the period considered in the simulation was 2020 to 2100 and the solar global radiation was calculated using the RadEst 3.00 software (FAO, ISCI: Rome, Italy) [41]. Specifically, the Campbell/Donatelli radiation model implemented in RadEst was used.

Observed weather data over the period 2000-2020, provided by the Protezione Civile della Regione Campania http:/ / centrofunzionale.regione.campania.it/ (accessed on 20 Semptember 2021) was used as reference climate to check the climate scenario forecast. For that period, the annual mean rainfall was about $829 \mathrm{~mm}$ and the mean air temperature was about $13.4^{\circ} \mathrm{C}$, with reference to the Ariano Irpino site (Campania region, Italy), which is at $28 \mathrm{~km}$ distance from the experimental site and at the same elevation.

\subsection{ARMOSA Model}

\section{Model Description}

The ARMOSA model simulates soil- and crop-related variables in response to agricultural management and pedoclimatic conditions. The model runs at a daily time step and consists in three main modules: (1) crop growth and development; (2) soil water dynamics; (3) $\mathrm{C}$ and $\mathrm{N}$ cycling.

The crop-growth simulation was based on the gross $C$ absorption following the WOFOST approach [42] with a substantial improvement: the canopy was divided into five layers with different light interception. For each crop, 65 parameters needed to be set. During previous model applications [43-45], most of these parameters' values had been set. In the present study, the most sensitive parameters (i.e., potential gross $\mathrm{C}$ adsorption, 
specific leaf area index (LAI), four cardinal temperatures for crop growth) were set using the measured data from the field experiment with an objective function based on yield and LAI. As for the crop development, the model calculates the growing degree days (GDD), the development rate (used in the assimilate partition and LAI estimation), and the vernalization factor. BBCH scale is used to indicate the crop stages. In this analysis, the GDD requirements and the base temperature, optimal minimum and maximum temperature, and cut-off temperature for each stage were defined based on the observed dates of the durum wheat. The crop development is based on GDD, which were calculated by applying a trapezoidal rule that is similar to the rule described by [46]. Photosynthates partitioning among plant organs is specific for each $\mathrm{BBCH}$ stage.

Water content was simulated for each soil layer by a daily bucket module where the soil profile is divided into layers, usually $5 \mathrm{~cm}$ thick. Each layer accumulates water until it reaches the field capacity; above this level, the model tries to transfer the water in excess to the layer below within the limit of the hydraulic conductivity. The water that cannot infiltrate the lower layer (because it exceeds the hydraulic conductivity, or the lower layers is already at saturation) is retained up to the saturation level. The water that tries to infiltrate from the top into a layer that is already at saturation point bounces back and (proceeding from the bottom to the top of the profile) can remain above the soil surface for the rest of the day. This module calculated the daily soil water content in each 5-cm layer as the results of the water input (rain and irrigation), water uptake by roots, and percolation. The simulation was strictly dependent on soil properties.

C- and N-related processes were simulated for each soil layer and implemented following the approach of the SOILN model [47], with the difference that each input of $\mathrm{C}$ and $\mathrm{N}$ was considered independently, with each one having its own decomposition rate and fate. The input could be of three types, to which correspond three types of organic $\mathrm{C}$ and $\mathrm{N}$ pools: stable, litter, and manure. Crop residues, being the input of the litter pool, decompose based on the tillage type, depth of soil incorporation, crop type, and organs. Mineral pools are carbon dioxide, ammonium, and nitrate. Mineral and organic pools were daily calculated for each layer as the results of soil processes, which are immobilization, mineralization of the organic pools $\mathrm{C}$ and $\mathrm{N}$, nitrification, crop uptake, nitrate leaching, denitrification, atmospheric deposition, ammonium volatilization, and nitrous oxide emissions. The processes were driven by the temperature and water level, which affected the microbial activity. The inputs were manure (e.g., dairy or swine slurry, dairy dung, digestate, sewage sludge) or litter (i.e., crop residues or green manure). The soil temperature was simulated according to $[48,49]$ (SWAT model); it was mainly driven by crop biomass, litter, the stable fraction of SOC, and SWC.

The model input requirements in the current study considered the following data:

(a) Soil data: soil properties (i.e., sand-\%, silt-\%, clay-\%, bulk density- $\mathrm{Mg} \mathrm{m}^{-3}$, SOC and $\mathrm{N}$ in stable, litter, and manure fractions $-\mathrm{kg} \mathrm{ha}^{-1}$, van Genuchten-Mualem equation parameters) are required for each pedological horizon. The horizons were further split into 5-cm layers for the daily estimation of the soil-related variables. In each layer, the state variables were water availability and percolation, evaporation, soil organic $\mathrm{C}$ and $\mathrm{N}$ in the three main pools (i.e., stable, litter, manure), ammonia, and nitrate. ARMOSA computed the daily values of bulk density and van Genuchten-Mualem equation parameters as affected by SOC content and tillage operations.

(b) Daily weather parameters were required as input data to compute the reference evapotranspiration $\left(\mathrm{mm} \mathrm{d}^{-1}\right)$ with the Hargreaves-reference evapotranspiration equation [29]. The required parameters were rainfall $(\mathrm{mm})$, minimum and maximum air temperature $\left({ }^{\circ} \mathrm{C}\right)$, wind speed at $2 \mathrm{~m}$ height $\left(\mathrm{m} \mathrm{s}^{-1}\right)$, and solar global radiation $\left(\mathrm{MJ} \mathrm{m}^{-2}\right)$.

(c) Crop data: the crop rotation had to be set and for each crop sown and harvested, dates had to be entered. The input for crop-residues management was the percentage of residues biomass retained and the soil depth of incorporation.

(d) Tillage date, type (perturbation and mixing effect), and soil depth had to be defined for each tillage event. 
(e) Fertilization: either mineral or organic fertilizers had possibly been applied. The amount of $\mathrm{kg} \mathrm{N} \mathrm{ha}^{-1}$, day of the year (DOY) of application, depth of application, the type of fertilizer (ammonium and nitrate content, $\mathrm{C} / \mathrm{N}$ ratio for organic fertilizers) had to be set.

\subsection{Model Parametrization and Calibration}

The model was calibrated for the prediction of the soil water content (SWC), leaf area index (LAI), and the aboveground biomass (AGB) collected in the two experimental sites located in Scampitella (South of Italy). Therefore, the ARMOSA model was calibrated using the set of measured data collected on the tillage $(\mathrm{T})$ treatment and on the no-tillage (No-T) treatment of the durum-wheat-cropping system during the 2013-2014 crop growing season.

The calibration methodology followed a trial-and-error procedure to minimize, with an iterative process, the error propagation in the simulated processes, as described in [50]. The trial-and-error procedure consisted, first, of finding the soil hydraulic parameters in the $\mathrm{T}$ and No-T management treatments for the different soil depths, until the variation of the differences in SWC sim-SWC field became negligible with few deviations from one iteration to the successive. This calibration of hydraulic properties was required for field applications to consider the well-known deviation between laboratory-measured and field-measured hydraulic properties [51-53].

Secondly, the same method was developed for the crop phenological stages and crop parameters in the $\mathrm{T}$ and No-T treatments, until low estimation errors were obtained, with negligible differences in successive iterations for the phenological dates, LAI, and AGB field data. Therefore, the same values of the crop calibrated parameters were used in the $\mathrm{T}$ and No-T treatments.

The performance of the model was assessed graphically and using the following goodness-of-fit indicators, which were employed and suggested in former modeling studies $[27,50,54]$.

For all the indexes, $O_{i}$ and $P_{i}$ relate to observed and predicted values for all studied variables and $\bar{O}$ and $\bar{P}$ are the mean of the observed and predicted variables, respectively.

(a) the Pearson's correlation coefficient $(r)$ [55] is a measure of the degree of association between simulations and observations. It varies between 0 -no agreement and 1 -full agreement between the simulated and observed data:

$$
r=\left\{\frac{\sum_{i=1}^{n}\left(O_{i}-\bar{O}\right)\left(P_{i}-\bar{O}\right)}{\left[\sum_{i=1}^{n}\left(O_{i}-\bar{O}\right)^{2}\right]^{0.5}\left[\sum_{i=1}^{n}\left(P_{i}-\bar{P}\right)^{2}\right]^{0.5}}\right\},
$$

(b) the relative root mean square error (RRMSE) [56] is a measure for the accuracy of the predictions, which needs to be equal or close to 0 , evidencing a perfect match between the simulated and observed variables.

$$
\operatorname{RRMSE}=\left[\frac{\frac{1}{n} \sum_{i=1}^{n}\left(O_{i}-P_{i}\right)}{\bar{O}}\right]^{0.5},
$$

(c) the average absolute error (AAE) represents the average error size associated with the estimations, and it varies between 0 - perfect match and positive infinitive - no match between the simulated and measured values:

$$
\mathrm{AAE}=\frac{1}{n} \sum_{i=1}^{n}\left|O_{i}-P_{i}\right|
$$

(d) the percent bias (PBIAS) [57] indicates the trend of the model predictions to be larger or smaller than the equivalent observed: positive values indicate an underestimation 
bias, while negative values correspond to an overestimation bias and values close to zero indicate the absence of trends:

$$
\text { PBIAS }=100 \frac{\sum_{i=1}^{n}\left(O_{i}-P_{i}\right)}{\sum_{i=1}^{n} O_{i}},
$$

(e) the efficiency index (EF) proposed by [58] varies between negative infinity and 1.0, whose positive values indicates that the model is a better forecast than the average of measured values:

$$
\mathrm{EF}=1-\frac{\sum_{i=1}^{n}\left(O_{i}-P_{i}\right)}{\sum_{i=1}^{n}\left(O_{i}-\bar{O}\right)},
$$

The calibrated model was run with the two climate scenarios RCP4.5 and RCP8.5, and the crop phenological stages were modified according to the climate trend observed (i.e., higher temperatures and lower rainfall events). Previous research predicted an elongation of the crop-growing season in future periods, and thus the model needs to be modified accordingly for future scenarios [18,59].

As a matter of fact, in this study, the sowing and harvesting dates were kept the same as those observed in the monitoring year. The flowering stage was anticipated and the time for grain maturity reduced to elongate the wheat growth cycle by adjusting the thermal requirements in growing-degree days from the tillering to the flowering stage and from watery ripeness to physiological maturity.

The following output parameters were analyzed in the model application: predicted grain yields, SOC content, $\mathrm{N}$ uptake, and water- and nitrogen-stress indexes; to verify their long-term trends and stabilities under the two soil-management techniques.

The one-way ANOVA model was applied to data, considering annual results as replicates, to find differences between $\mathrm{T}$ and No-T, and the homogeneity of variances was tested using Levene's mean-based test [60] following the suggestions of [61].

\section{Results}

\subsection{Soil Survey Results and Plot Definition}

A preliminary scan of the two fields was performed by EMI sensors to investigate the soil variability in both fields and, thus, define the experimental plots.

Most of the area-excluding some spots-showed similar values of ECa between the range $60-80 \mathrm{~ms} \mathrm{~cm}^{-1}$. This homogeneous response of the soil profile cannot be directly reflected in a soil homogeneity, because the ECa is an integrated value that depends on many factors such as soil texture, layering, water content, and salinity-different combinations of which can produce similar results. Therefore, two profiles were open in zones showing the same value of ECa, respectively in the T and No-T field (black circles in the Figure 3), on the base of this first hypothesis on homogeneity.

Both soil profiles are Calcic Vertisols according to the World Reference Base (WRB) classification system [62]. In Table 3 the main characteristics of the soil profiles are reported. Only minor differences arose between the two profiles in genetic horizons, $\mathrm{pH}$, carbonates, and CEC. Hence, the possible differences in the results obtained in the two experimental plots cannot be attributed to differences in soils but-reasonably-only to the different tillage of the upper layer, i.e., conventional and no-tillage.

Table 3. Soil profile characteristics for $\mathrm{T}$ and No-T experimental sites.

\begin{tabular}{cccccccc}
\hline Site & Soil Profile & Depth & $\mathbf{p H}\left(\mathbf{H}_{\mathbf{2}} \mathbf{O}\right)$ & O.C $(\mathbf{\%})$ & $\mathbf{C a C O}_{\mathbf{3}}(\mathbf{\%})$ & $\mathbf{E . C}\left(\mathbf{m s ~ c m}{ }^{-\mathbf{1}}\right)$ & $\mathbf{C . E . C}(\mathbf{m e q} / \mathbf{1 0 0} \mathbf{g})$ \\
\hline & Ap1 & $0-10$ & 8.4 & 1.4 & 12.4 & 275 & 39 \\
& Ap2 & $10-40$ & 8.4 & 1.3 & 10.9 & 183 & 33 \\
$\mathrm{~T}$ & Bss1 & $40-65$ & 8.7 & 0.9 & 12.3 & 315 & 36 \\
& Bss2 & $65-90$ & 8.8 & 0.8 & 18.9 & 392 & 29 \\
& Bss3 & $90-105$ & 8.8 & 0.6 & 20.5 & 564 & 34 \\
\hline
\end{tabular}


Table 3. Cont.

\begin{tabular}{|c|c|c|c|c|c|c|c|}
\hline Site & Soil Profile & Depth & $\mathrm{pH}\left(\mathrm{H}_{2} \mathrm{O}\right)$ & O.C (\%) & $\mathrm{CaCO}_{3}(\%)$ & E.C $\left(\mathrm{ms} \mathrm{cm}^{-1}\right)$ & C.E.C (meq/100 g) \\
\hline & $\mathrm{Bw}$ & $105-120$ & 8.8 & 0.6 & 18.7 & 697 & 24 \\
\hline & $\mathrm{CB}$ & $120-150$ & 8.8 & 0.5 & 24.9 & 789 & 28 \\
\hline \multirow{7}{*}{ No-T } & Ap1 & $0-10$ & 8.1 & 1.2 & 10.5 & 252 & 33 \\
\hline & Ap2 & $10-45$ & 8.3 & 1.1 & 10.1 & 177 & 33 \\
\hline & Bss1 & $45-100$ & 8.4 & 0.7 & 13.3 & 372 & 31 \\
\hline & Bss2 & $100-120$ & 8.5 & 0.7 & 17.4 & 317 & 31 \\
\hline & 2Bss & $120-130$ & 8.5 & 0.5 & 18.2 & 271 & 31 \\
\hline & $2 \mathrm{CB}$ & $130-160$ & 8.5 & 0.4 & 22.2 & 271 & 23 \\
\hline & $2 \mathrm{C}$ & $160-170$ & 8.6 & 0.5 & 29.1 & 247 & 18 \\
\hline
\end{tabular}

O.C = Organic carbon; E.C = electric conductivity; C.E.C = cation exchange capacity.

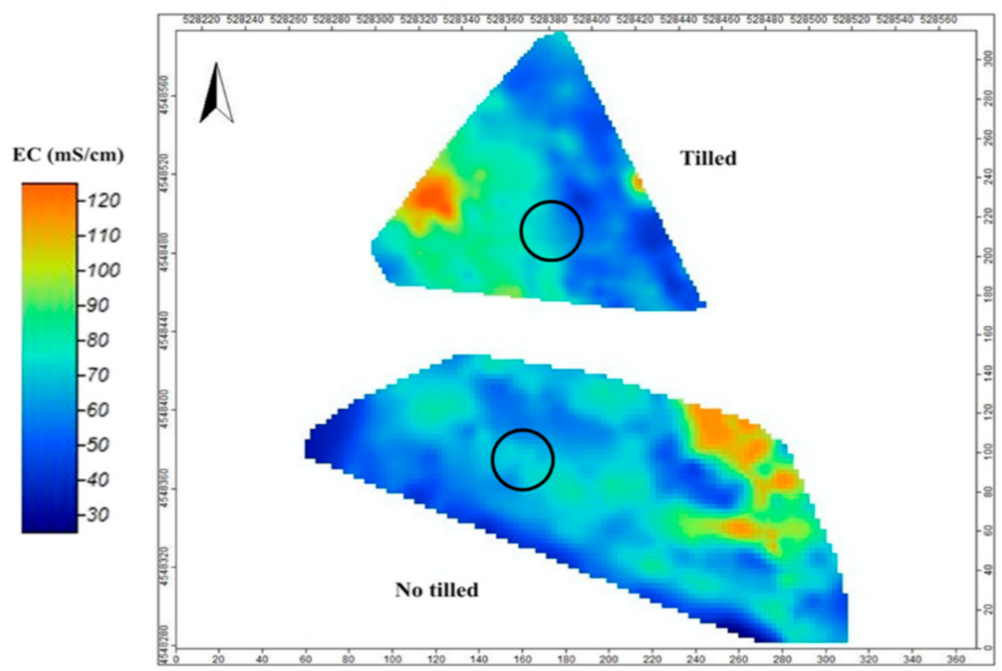

Figure 3. Maps of apparent electrical conductivity (ECa) measured at the Scampitella field.

According to these preliminary results, the experimental plots of $\mathrm{T}$ and No-T were selected near to the profiles, and their location is reported in Figure 3 with a black circle.

\subsection{Parameter's Calibration of the Durum Wheat Crop Growth Model}

The ARMOSA model was calibrated using SWC measurements, LAI, and AGB in both $\mathrm{T}$ and No-T treatments for the entire crop-growing season.

Figure 4 shows the match between measured and simulated SWC values during the crop-growing season 2013-2014 at 0-15-cm $(\mathrm{n}=123), 20-\mathrm{cm}(\mathrm{n}=133), 40-\mathrm{cm}(\mathrm{n}=194)$, and $50-\mathrm{cm}(\mathrm{n}=194)$ depths regarding the $\mathrm{T}$ treatment. The results show that the temporal variations of both measured SWC and estimated SWC are reasonably well-described for the whole period and for the four depths. Moreover, the model responded well to the peaks and absence of rainfall events.

The calibration indicators for the four soil depths and the entire soil profile are reported in Table 4. Overall, the goodness-of-fit indicators performed well for the four soil depths and along the soil profile, with slight differences between the more superficial and the deepest soil layer. The Pearson's correlation coefficient $r$ values were high in the $0-15-\mathrm{cm}, 20-\mathrm{cm}$, and 50-cm depths $(\mathrm{r}=0.91-0.88)$ and acceptable in the 40-cm depth $(\mathrm{r}=0.51)$, which indicates that the model represented with good accuracy the variability of the SWC in each layer.

The model underestimates the SWC at $20 \mathrm{~cm}$ with a PBIAS of $13.1 \%$, while smaller PBIAS values (0.6-2.4\%) were found in the other depths with no trend of under- or overestimation of the simulated values. Estimation errors are small in all depths, as indicated by the RRMSE $<16 \%$ and AAE $<0.05 \mathrm{~m}^{3} \mathrm{~m}^{-3}$. The Nash and Sutcliffe efficiency index EF was high for the superficial layer $(E F=0.79)$, acceptable in the 20-cm layer $(E F=0.23)$, and 
negative for the deepest layers $(E F=-0.05 ;-0.43)$, which means that the mean square error was higher than the measured data variability.
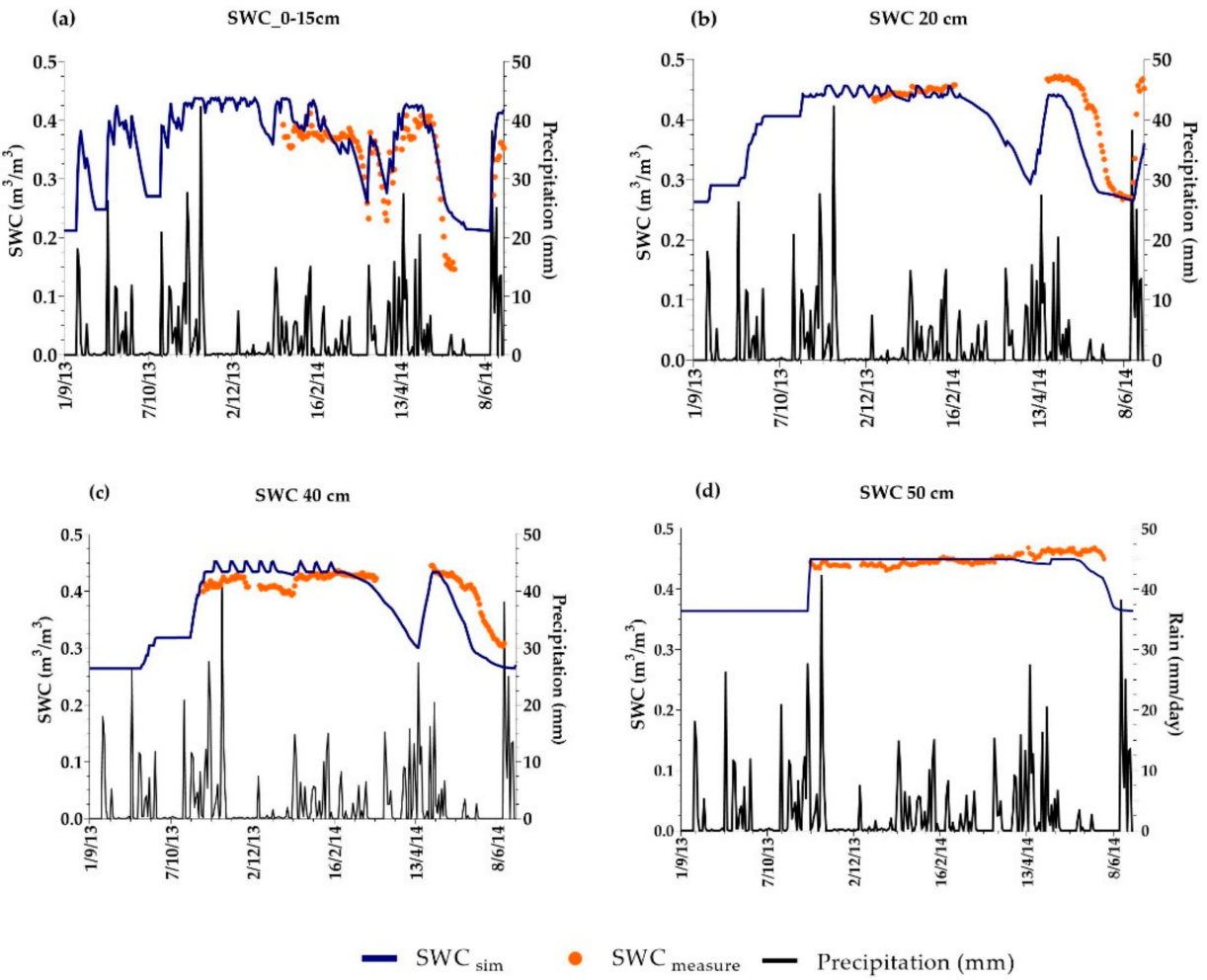

Figure 4. Soil water content measured with TDR (SWC measure, $\bullet$ ) and simulated with ARMOSA

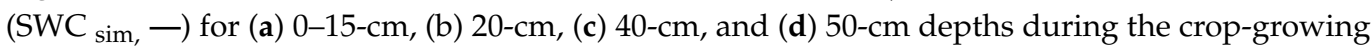
season 2013-2014 in the T treatment.

Table 4. Calibration indicators relative to the SWC $\left(\mathrm{SWC}_{\mathrm{sim}}\right)$ simulated with the ARMOSA model compared to the SWC obtained from TDR measurements (SWC measure) for 0-15- $\mathrm{cm}, 20-\mathrm{cm}, 30-\mathrm{cm}$, $40-\mathrm{cm}$, and $50-\mathrm{cm}$ depths and for the entire soil profile $(0-50 \mathrm{~cm})$ in the $\mathrm{T}$ and No-T treatments.

\begin{tabular}{cccc}
\hline & & \multicolumn{2}{c}{ Treatments } \\
\cline { 2 - 4 } Depths $(\mathbf{m})$ & $\mathbf{T}$ & No-T \\
\cline { 3 - 4 }$r$ & $0-15$ & 0.90 & 0.83 \\
& 20 & 0.88 & 0.82 \\
& 30 & $\mathrm{NA}$ & 0.79 \\
& 40 & 0.51 & $\mathrm{NA}$ \\
& 50 & 0.91 & -0.49 \\
& $0-50$ & 0.86 & 0.83 \\
\hline \multirow{2}{*}{ PBIAS (\%) } & $0-15$ & 2.4 & -6.7 \\
& 20 & 13.1 & 7.8 \\
& 30 & $\mathrm{NA}$ & 1.1 \\
& 40 & 1.4 & $\mathrm{NA}$ \\
& 50 & 0.6 & 0.4 \\
& $0-50$ & 3.5 & 0.9 \\
\hline & $0-15$ & 8.04 & 12.11 \\
& 20 & 15.83 & 12.56 \\
& 30 & $\mathrm{NA}$ & 9.2 \\
& 40 & 8.73 & $\mathrm{NA}$ \\
& 50 & 4.92 & 3.11 \\
& $0-50$ & 9.34 & 9.1 \\
\hline
\end{tabular}


Table 4. Cont.

\begin{tabular}{cccc}
\hline & & \multicolumn{2}{c}{ Treatments } \\
\cline { 2 - 4 } Depths $(\mathbf{m})$ & T & No-T \\
\cline { 3 - 4 } AAE $\left(\mathrm{m}^{3} / \mathrm{m}^{3}\right)$ & $0-15$ & 0.02 & 0.03 \\
& 20 & 0.05 & 0.03 \\
& 30 & $\mathrm{NA}$ & 0.03 \\
& 40 & 0.03 & $\mathrm{NA}$ \\
& 50 & 0.02 & 0.01 \\
& $0-50$ & 0.03 & 0.03 \\
\hline & $0-15$ & 0.79 & 0.55 \\
& 20 & 0.23 & 0.32 \\
& 30 & $\mathrm{NA}$ & -0.47 \\
& 40 & -0.43 & $\mathrm{NA}$ \\
& 50 & -0.05 & -1.15 \\
& $0-50$ & 0.59 & 0.59 \\
\hline
\end{tabular}

As in the T treatment, calibration results showed good agreement between simulated and measured SWC data at $0-15-\mathrm{cm}(\mathrm{n}=125) ; 20-\mathrm{cm}(\mathrm{n}=128), 30-\mathrm{cm}(\mathrm{n}=169)$, and $50-\mathrm{cm}$ $(\mathrm{n}=186)$ depths for the No-T treatment. The simulated SWC followed the temporal SWC measured (Figure 5), and the statistical indicators depict similar ranges as the ones for the $\mathrm{T}$ treatment (Table 4).
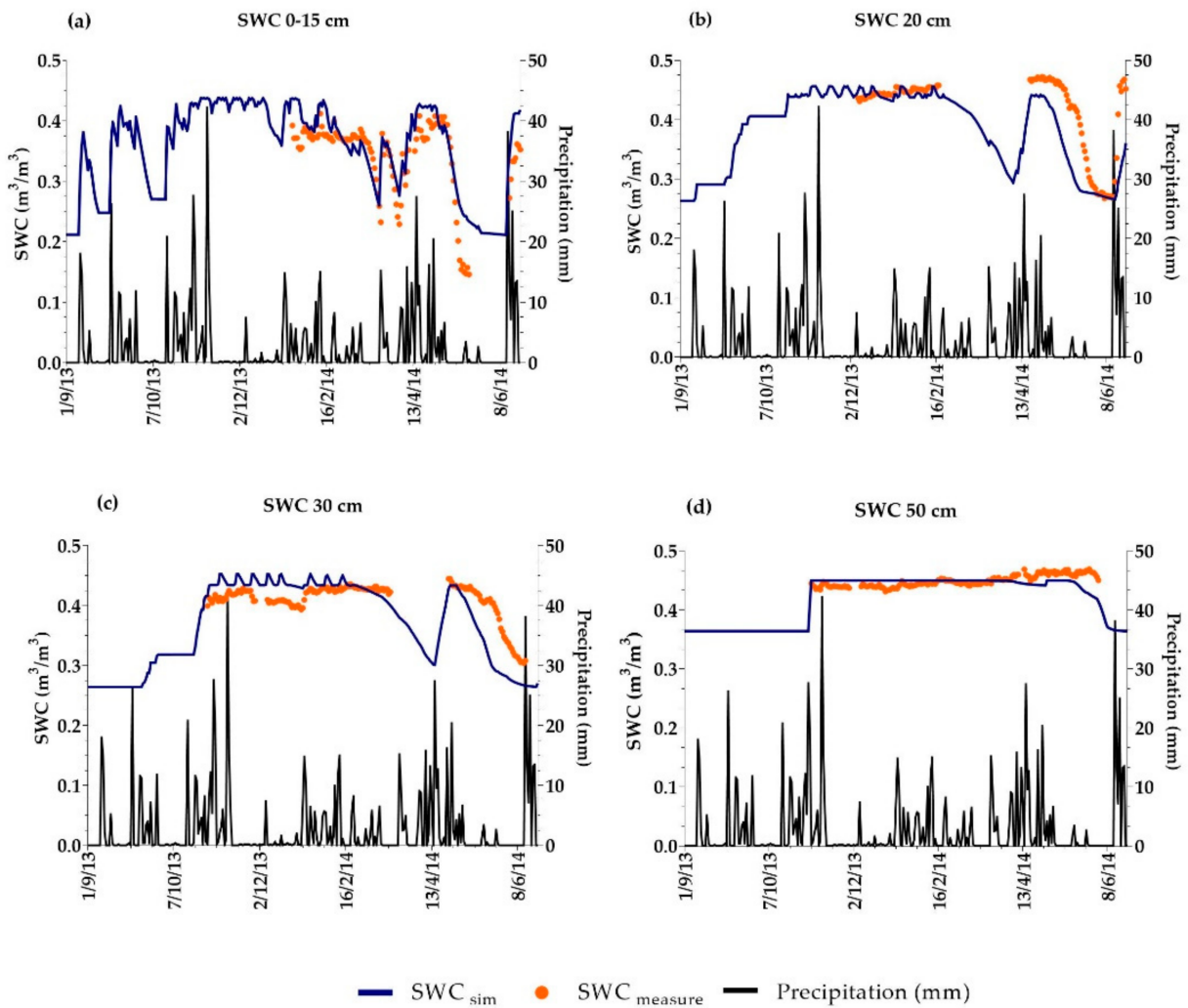

Figure 5. Soil water content measured with TDR (SWC measure, $\bullet$ ) and simulated with ARMOSA (SWC sim, -) for (a) 0-15-cm, (b) 20-cm, (c) 30-cm, and (d) 50-cm depths during the crop-growing season 2013-2014 in the No-T treatment.

The $\mathrm{r}$ coefficient was near to 1.0 in the more superficial depths, which indicates a good linear correlation between the simulated and measured data sets in the first three depths investigated $(\mathrm{r}=0.83-0.79)$. Contrarily to that observed in the $\mathrm{T}$ treatment, the $\mathrm{r}$ index at $50 \mathrm{~cm}$ is lower than those in the upper layers. The PBIAS results were acceptable and did 
not perform any significant over- or underestimation trend of the model output in any of the soil layers. Estimation errors RRMSE and AAE were in the same range as the ones in the $\mathrm{T}$ treatment for each soil layer investigated.

In the same line, the EF index performed similar values that those in the T treatment output, which depicted satisfactory $E F$ in the upper layers $(E F=0.55-0.32)$ and negative value in the lower layers $(\mathrm{EF}=-0.47 ;-1.15)$.

Measurements of LAI and AGB for the whole crop-growing season in the T and No-T management methods were used for further calibration of ARMOSA. Figure 6 represents simulated LAI and AGB obtained with the calibrated model parameters compared with the measured $\mathrm{LAI}_{\text {measure }}$ and $\mathrm{AGB}_{\text {measure }}$ data, and Table 5 reports the statistical indices outcomes from the model calibration. The results illustrate that the simulated LAI and AGB adequately fits the measured variables.

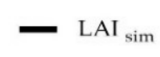

LAI T
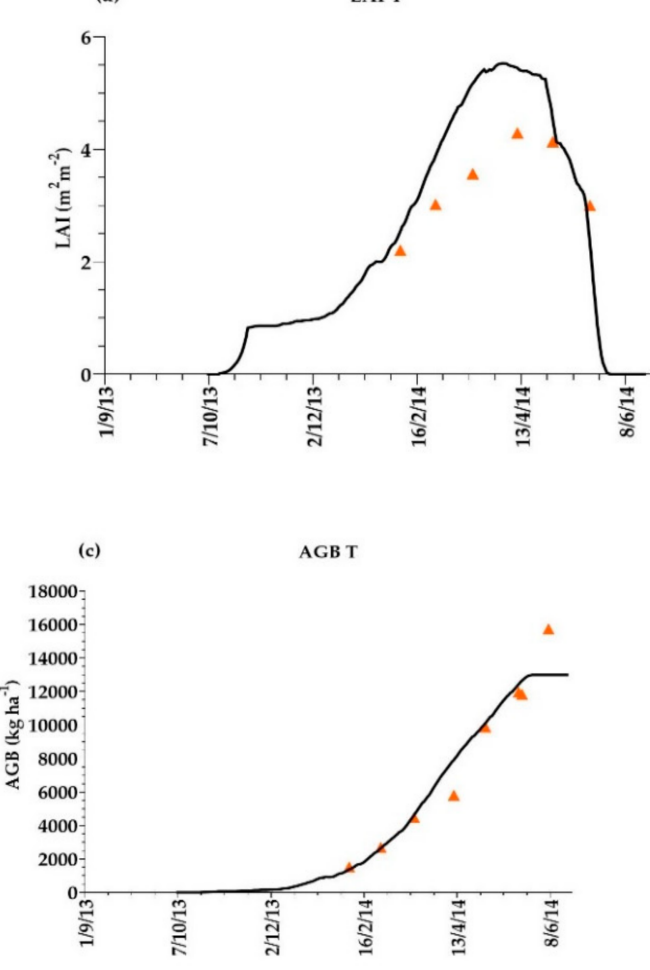

(b)
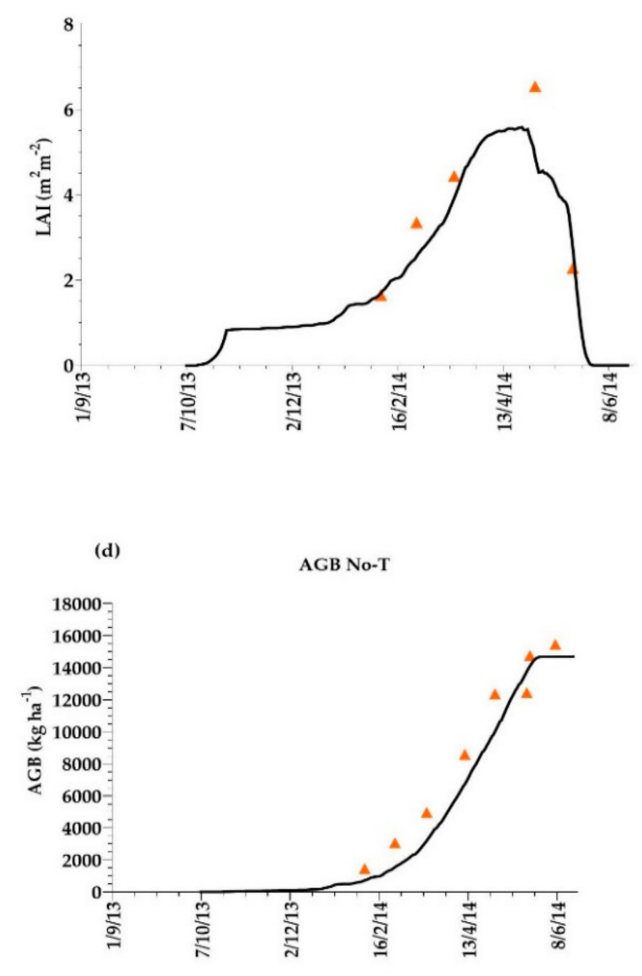

A $\mathrm{AGB}$ measure

Figure 6. Crop leaf area index $\left(\mathrm{LAI}_{\text {measure, }} \Delta\right)$ and aboveground biomass ( $\left.\mathrm{AGB}_{\text {measure, }} \Delta\right)$ measured and $\left(\mathrm{LAI}_{\text {sim }}-; \mathrm{AGB}_{\text {sim }}-\right)$ simulated with ARMOSA for durum wheat under $\mathrm{T}(\mathbf{a}, \mathbf{c})$ and No-T $(\mathbf{b}, \mathbf{d})$ management during the crop-growing season 2013-2014.

The model calibration indices (Table 5) are acceptable for LAI and good for AGB predicted values. In both treatments, the Pearson's correlation coefficient $r$ is high $(0.98-0.84)$ for LAI and AGB, which reflects high correlation of the simulated and measured variables. In the same way, the estimation errors RRMSE and AAE are acceptable for the LAI and small for the AGB variable.

The PBIAS is small for the AGB variable and LAI in the No-T but indicates an overestimation by the model of the LAI measured values $(-18.2 \%)$ in the T treatment. This may be related to the fact that the LAI measured values in the No-T management were 
1.25-1.50 times higher than the ones in the T management, which may cause the overestimation of the LAI in the No-T management.

Table 5. Calibration indicators associated with the LAI ( $\left.\mathrm{LAI}_{\text {sim }}\right)$ and $\mathrm{AGB}\left(\mathrm{AGB}_{\text {sim }}\right)$ simulated with the ARMOSA model compared to the LAI ( $\mathrm{LAI}_{\text {measure}}$ ) and AGB ( $\mathrm{AGB}_{\text {measure }}$ ) obtained from field measurements for durum wheat under the $\mathrm{T}$ and No-T management methods.

\begin{tabular}{ccccc}
\hline & \multicolumn{2}{c}{ LAI } & \multicolumn{2}{c}{ AGB } \\
\hline & T & No-T & T & No-T \\
\hline$r$ & 0.84 & 0.92 & 0.96 & 0.98 \\
PBIAS $(\%)$ & -18.2 & 13.3 & 1.3 & 11.4 \\
RRMSE $(\%)$ & 28.07 & 24.11 & 15.92 & 16.27 \\
AAE $\left(\mathrm{m}^{2} / \mathrm{m}^{2}\right)$ & 0.84 & 0.70 & 836 & 1370.12 \\
EF & -0.74 & 0.74 & 0.93 & 0.91 \\
\hline
\end{tabular}

Similarly, the EF index regarding the LAI calibration in the T is negative $(-0.73)$, which could be due to the small difference between the minimum and maximum measured values of LAI. The predicted values could not simulate the small range of measured values, but the simulated curve fitted the pattern of the measured values.

On the other hand, the EF index of the AGB prediction is high $(E F=0.93-0.91)$, which shows that the simulations of AGB have a small error with respect to the variance of observations.

According to this statistical evaluation, the calibration of ARMOSA for durum wheat cultivated with $\mathrm{T}$ and No-T was performed satisfactorily, even better than similar experiments $[3,4,21]$.

\subsection{Simulations with Climate-Change Scenarios}

The simulation results obtained by the ARMOSA model for the two climate scenarios during the 2020-2100 period, three timeframes (2020-2040, 2040-2070, 2070-2100), and the two soil-management treatments are presented in Figure 7 as box-plot graphs. The average yields of the No-T treatment are 5.2\% and $11.4 \%$ higher than the $\mathrm{T}$ treatment yield in the 4.5 and 8.5 climate-change scenarios, respectively, when considering the period 2020-2100. The difference of the average yield between the two soil-management techniques is not statistically significant $(p>0.05)$ in the RCP4.5 scenario but is statistically significant in the RCP8.5 scenario $(p<0.05)$.

The yield difference between the two soil-management treatments becomes more pronounced as time advances, and is always higher in the No-T treatment. For instance, yield difference reaches the minimum in the two scenarios during the 2020-2040 timeframe $(0.37 \%$ and $4.12 \%$ in the 4.5 and 8.5 RCP scenarios, respectively), and it will be maximum during 2040-2070 in the RCP8.5 scenario (15\%) and in 2070-2100 considering the RCP4.5 scenario $(12 \%)$.

It could be observed from Figure 7 that the yield variability is slightly higher in the No$\mathrm{T}$ management in comparison to the $\mathrm{T}$ in both scenarios and for each timeframe considered. However, this difference is not statistically significant $(p>0.05)$ in any case considered, as shown by the Levene test. In addition, the largest variability of the average yield is observed in the RCP8.5 scenario in both soil-management techniques.

The evolution of the total SOC in the first $30 \mathrm{~cm}$ of soil along the future period for both climate scenarios (Figure 8) is improved when the No-T treatment is implemented in durum wheat in this pedoclimatic context. The SOC content remains constant during the first years of implementation of the No-T management, then starts to increment constantly with an average annual growth rate of $0.19 \%$ year $^{-1}$ in the RCP4.5 scenario and $0.20 \%$ year $^{-1}$ in the RCP8.5 scenario, until it reaches a constant value. On the contrary, the use of T management in durum wheat will produce a constant reduction of the soil carbon content with an average annual growth rate of $-1.32 \%$ year $^{-1}$ in the RCP4.5 scenario 
and $-1.35 \%$ year $^{-1}$ in the RCP8.5 scenario, until it reaches a minimum value around $10,000 \mathrm{~kg} \mathrm{ha}^{-1} \mathrm{SOC}$.
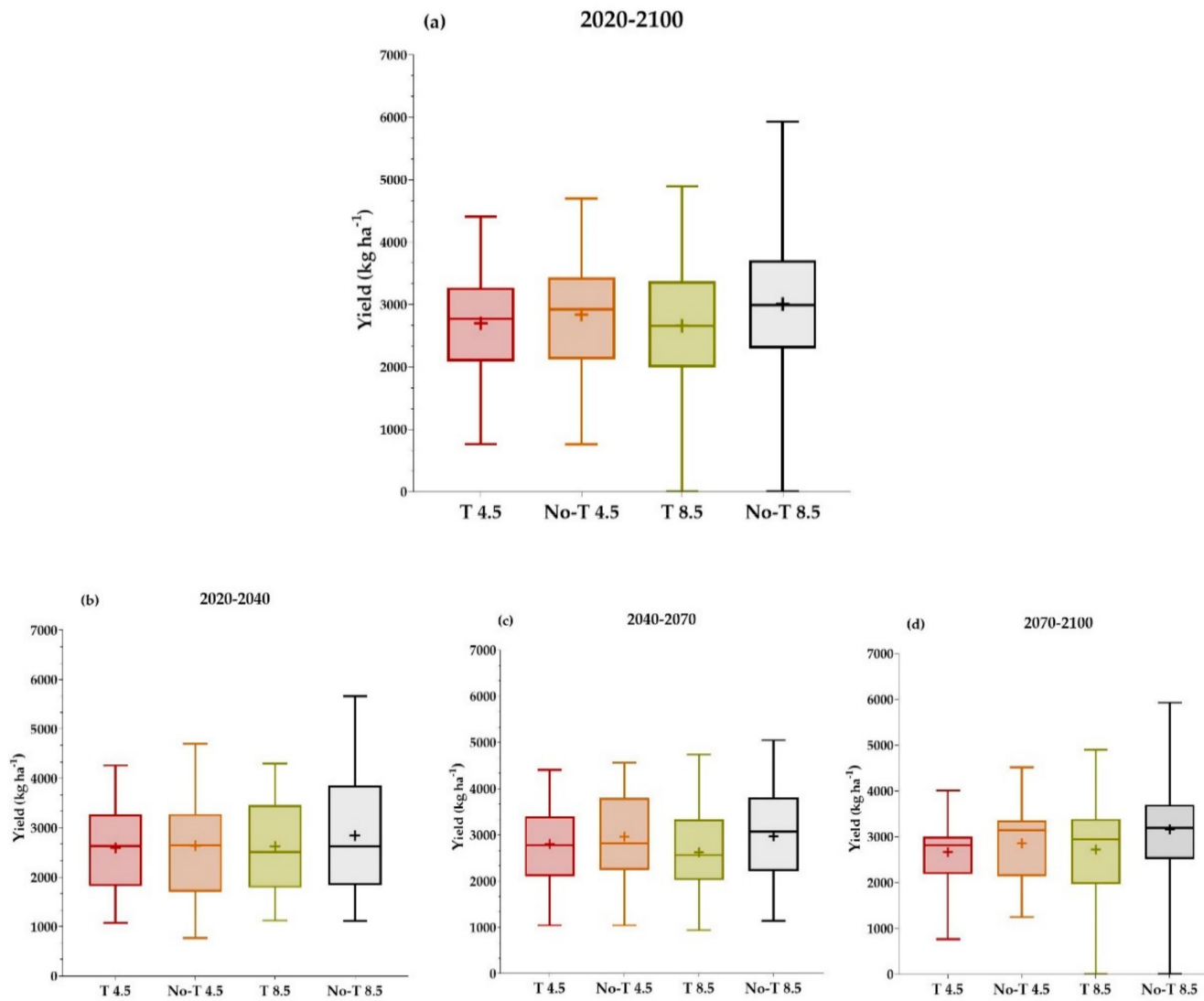

Figure 7. Boxplot of durum-wheat grain yield under $\mathrm{T}$ and No-T management in the analyzed climate scenarios and their respective time periods (a) 2020-2100, (b) 2020-2040, (c) 2040-2070, and (d) 2070-2100.

(a) Total soil organic carbon RCP4.5

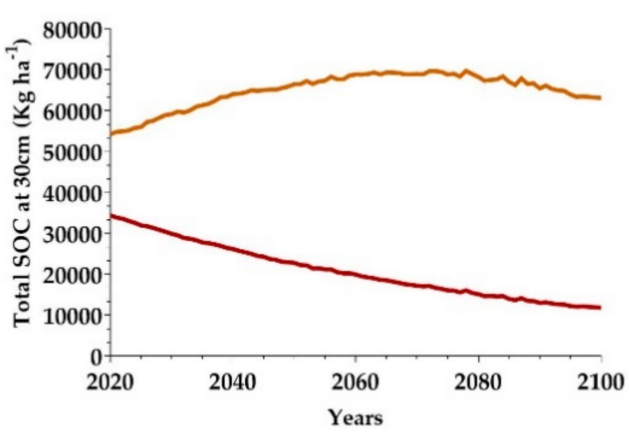

- T RCP4.5 - No-T RCP4.5 (b) Total soil organic carbon RCP8.5

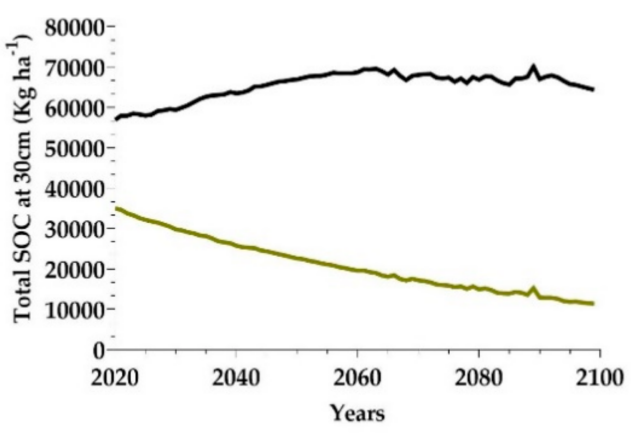

- T RCP8.5 - No-T RCP8.5

Figure 8. Simulated total soil organic carbon (SOC) at $30 \mathrm{~cm}$ under $\mathrm{T}$ and No-T for the RCP4.5 (a) and RCP8.5 (b) climate-change scenarios during the period 2020-2100.

As a matter of testing, we calculated the relationship of the SOC in both treatments, $\mathrm{I}_{\mathrm{SOC}}=\mathrm{SOC}_{\mathrm{T}} / \mathrm{SOC}_{\mathrm{No}-\mathrm{T}}$, as measured at the beginning of the experiment in 2013 , measured after 8 years in 2021, and modeled for both RCP scenarios for 2013 and 2021. The results are reported in Table 6. 
Table 6. ISOC between T and No-T SOC in the 2013 and 2021 seasons, measured and simulated for both climate scenarios.

\begin{tabular}{cccccc}
\hline Measured 2013 & $\begin{array}{c}\text { Simulated 2013 } \\
\text { RCP4.5 }\end{array}$ & $\begin{array}{c}\text { Simulated 2013 } \\
\text { RCP8.5 }\end{array}$ & Measured 2021 & $\begin{array}{c}\text { Simulated 2021 } \\
\text { RCP4.5 }\end{array}$ & $\begin{array}{c}\text { Simulated 2021 } \\
\text { RCP8.5 }\end{array}$ \\
\hline $108 \%$ & $75 \%$ & $75 \%$ & $84 \%$ & $62 \%$ & $60 \%$ \\
\hline
\end{tabular}

Consequently, the different trends in the SOC in the two soil-management systems of durum wheat under these pedoclimatic conditions can be predicted by the ARMOSA model for future climate projections.

The $\mathrm{N}$ uptake will be much higher when the No-T technique is used, depicting an annual average change of $3.55 \%$ year $^{-1}$ in the RCP4.5 scenario and $3.18 \%$ year $^{-1}$ in the RCP8.5 scenario, which at the same time will reduce the $\mathrm{N}$ leaching (Figure 9). The No-T system will not experience $\mathrm{N}$ stress, although the uptake is higher in this management (Table 7). On the other hand, the system under T will not absorb as much $\mathrm{N}$ as the No-T, depicting $1.57 \%$ year ${ }^{-1}$ and $1.73 \%$ year ${ }^{-1}$ of average annual change, respectively for the RCP4.5 and RCP8.5 scenarios; and thus, it won't be able to produce much more yield, as explained previously.

(a)

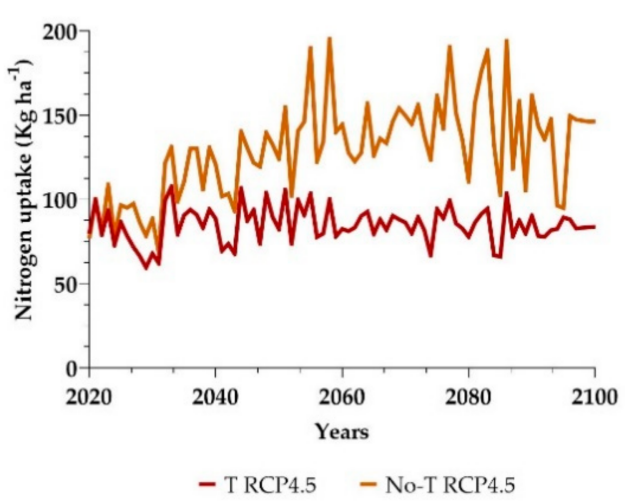

(b)

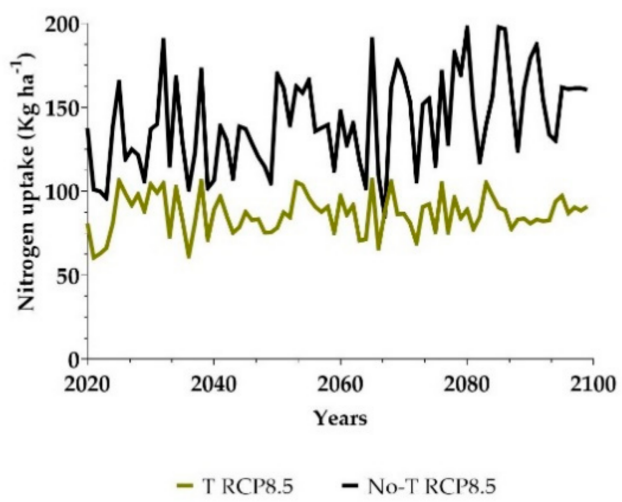

Figure 9. Simulated nitrogen uptake under T and No-T for the (a) RCP4.5 and (b) RCP8.5 climatechange scenarios during the 2020-2100 period.

Table 7. Simulated average water-stress index and average nitrogen-stress index under T and No-T for the RCP4.5 and RCP8.5 climate-change scenarios during the 2020-2100 period.

\begin{tabular}{ccc}
\hline & Average of Water-Stress Index & Average of Nitrogen-Stress Index \\
\hline T RCP4.5 & 0.66 & 0.96 \\
No-T RCP4.5 & 0.58 & 1.00 \\
T RCP8.5 & 0.68 & 0.94 \\
No-T RCP8.5 & 0.61 & 1.00 \\
\hline
\end{tabular}

Table 7 shows the $\mathrm{N}$ and water stresses that the crop system will experience in the future period. Neither technique will give any important stress. The difference in water stress between the two techniques will be small, although there may be more stress in the No-T treatment because the crop system will produce more, and, thus, consume more water. The residues kept in the soil decrease the evaporation process and the crop may be able to use water more efficiently, which may lead to a higher water consumption, and, thus, a slightly higher water-stress index.

\section{Discussion}

\subsection{Performance of ARMOSA with Durum Wheat under Tillage and No Tillage Techniques}

The crop-growth ARMOSA model was successfully calibrated as suggested by the goodness-of-fit indicators, for durum wheat cultivated with $\mathrm{T}$ and No-T soil-management 
techniques. Therefore, the model-for this pedoclimatic environment-could function as a good predictor of the durum-wheat yield as well as the SWC, N-leaching, and change in SOC dynamics to evaluate the effects of different soil management.

Specifically, the model performed better for the SWC in the $0-15-\mathrm{cm}, 20-\mathrm{cm}$, and $30-\mathrm{cm}$ depths, while for the $40-\mathrm{cm}$ and $50-\mathrm{cm}$ depths the model showed negative EF values, which indicates that it was not able to accurately predict the variance of the measured variable in both soil-management treatments. The negative EF value in the deepest soil layers could be explained by the fact that the soil bucket model better represents the processes within the root system, because the model simulates the root's water uptake and the transpiration, but it does not simulate the drainage. Consequently, the bucket model could present more difficulties in modeling the processes that occur in the deepest soil layers.

The model results for SWC are comparable in terms of accuracy with previous studies that simulated SWC using different process-based models for wheat and field crops cultivated following T and CA. For instance, Perego et al. (2013) [27] found close statistical indicators $(\mathrm{r}=0.68, \mathrm{RRMSE}=6.28, \mathrm{EF}=0.52)$ when calibrating and validating ARMOSA for SWC at different depths in the Lombardia plain (North Italy). Near the same experimental area, Bonfante et al. (2010) [63] compared three physically based models (SWAP, $\mathrm{MACRO}$, and CropSyst) on two sites that were cultivated with maize using conventional and minimum tillage. The authors found similar goodness-of-fit indicators to the ones in our study-specifically, the EF was negative in the deepest soil layers, which was attributed to the simplification of the complex water flow mechanisms through the soil profile by the models. In addition, the authors found higher absolute errors at the $0-15$-cm depths as in this study, which was related to the higher inaccuracy of the TDR in the superficial layers [63].

Liu et al. (2013) [6] found a slightly higher number of estimation errors (nRMSE = 15.3-20.0\%) than the in this study, in calibrating the DSSAT model in a soybean-maize crop rotation cultivated with $\mathrm{T}$ and $\mathrm{CA}$. The authors stressed that the poorer agreement in some simulation years can be related to potential outliers in the SWC measurements. In the same line, Devkota et al. (2015) [4] evaluated the DSSAT model in a rice-wheat rotation under zero tillage and water-saving strategies in Central Asia. The authors reported a close number of estimation errors (nRMSE $=6-8 \%$ ) compared with this study for different soil depths.

Shafeeq et al. (2020) [21] predicted the SWC in the $0-45 \mathrm{~cm}$ of the soil profile during the flowering stage of durum wheat using HYDRUS 2D, with similar goodness-of-fit indicators to those used in our study. However, these authors presented fewer measured data $(\mathrm{n}=18)$ of SWC than in our study, with measurements taken solely during the flowering stage. Consequently, ARMOSA could be used as a tool to see the changes that diverse soil management may cause in the SWC at different soil depths.

The ARMOSA calibration indicators for LAI and AGB that were obtained in this study are generally comparable with previous simulation studies for durum wheat and field crops under T and CA. Perego et al. (2013) [27] used ARMOSA to predict crop variables for field crops in six different sites from the Lombardia plain (Italy), with similar goodness-of-fit indexes for AGB $(r=0.97, \mathrm{RRMSE}=11.18, \mathrm{EF}=0.94)$ and LAI maximum value $(\mathrm{r}=0.72$, $\mathrm{RRMSE}=8.24, \mathrm{EF}=0.37)$.

Bechini et al. (2006) [64] parameterized the CropSyst model [65] for winter wheat by using data sets of four monitoring sites from the Lombardia plain. The calibration indicator RRMSE for the AGB was in the same range as the one in our study, (RRMSE = 9-30\%) but AGB was underestimated during the growth period (PBIAS $=21 \%$ ). The authors attributed this underestimation of crop growth rates to the linear relationship adopted by the model between the average air temperature and radiation dependent biomass accumulation, which may not represent accurately a biological phenomenon.

Ahmed et al. (2016) [18] evaluated the CERES and APSIM [66] models for five wheat cultivars under rainfed conditions in Pakistan. The authors reported comparable estimation errors (RRMSE < 10\%) for the maximum LAI and AGB. 
Comparable to our study, Corbeels et al. (2016) [22] calibrated the DSSAT model [67] for maize grown with $\mathrm{T}$ and was validated in the No-T with mulch treatment. The authors reported high overestimation (PBIAS $=-51 \%$ ) in simulating the AGB of maize during the calibration process. The authors argued that this could be due to the large variability in the measured AGB for a certain season, which feature the DSSAT model was not able to capture.

As depicted in the Figure 6, the LAI measured was higher in the No-T by 1.5 units, which difference has been acceptably well-reproduced by the model output in the calibration process. Similar outcomes were reported by Shafeeq et al. (2020) [21] in durum wheat under No-T and residue management. The predicted values could not simulate the small range of measured values, but the simulated curve fitted the pattern of the measured values. Using the same model, Valkama et al. (2020) [28] found low EF and correlation coefficient when calibrating and validating ARMOSA with SOC content for different soil-management treatments in Almalybak (Kazakhstan). The authors suggested that the reason could be that the fewer measurements did not capture the trends of soil carbon evolution. Therefore, the ARMOSA model is able to reproduce the changes in crop features that the No-T and T applications could produce.

A key point in using the ARMOSA model to investigate the possible impacts of the two trials ( $\mathrm{T}$ and No-T) relies on the detailed field investigation of the soil spatial variability. Many of the papers reported above are missing a deeper knowledge of the soil differences between the experimental fields. These researches assume a priori homogeneity of the soil and therefore, they mix the management effects with the soil variability. In addition, papers applying statistical techniques to reduce the spatial variability (e.g., randomized blocks) produce a smoothing of the results, thus hampering the model calibration.

Even if our analysis indicates the No-T system as an interesting approach, the farmer's decision was based on the use of the herbicide glyphosate. Nevertheless, the scientific community has been working for years in developing alternatives to this herbicide, based on natural products and improved management techniques. A set of alternative techniques to perform CA without glyphosate are already available [68]. Moreover, in Europe, where cropping of GMO crops is not allowed, the glyphosate can be used only in pre-sowing, when it is easier to replace its use with mechanical weeding, or with very shallow tillage, such as disk harrowing.

\subsection{Application of ARMOSA in T and No-T Managements under Two Future Climate-Change Scenarios}

The future climate-change scenarios project an increase in temperature and decrease in rainfall in the south of Italy [69]. Therefore, finding feasible solutions to carry resilient and sustainable agriculture becomes imperative.

The application of the ARMOSA crop-based model in durum wheat cultivated with $T$ and No-T managements forecast higher average yields when the No-T is used in both the RCP4.5 and RCP8.5 scenarios. This difference in yield will be $5 \%$ higher for the 4.5 scenario $(p>0.05)$ and $11 \%$ in the 8.5 scenario $(p<0.05)$ for the $2020-2100$ period. The bigger and more statistically significant yield difference in the RCP 8.5 compared to the RCP4.5 could be related to the prediction of higher increase of annual temperature and reduction in precipitation in the RCP8.5, as highlighted in previous studies about the climate-change effects on wheat yield $[20,44,70]$. In this way, No-T management may become more crucial as the climate forecast becomes more extreme.

Moreover, similar results on yield difference between soil-management techniques have been reported in literature $[3,19,71]$. In the same line as in our study, Bahri et al. (2019) [3] used the APSIM model to predict the effect of T and No-T with residue retention on wheat productivity in Tunisia in future climate scenarios. The study concluded that No-T with residue retention can increase wheat yield by $15 \%$ compared to $\mathrm{T}$ under climate-change conditions. 
Simulations depicted slightly higher yield variability in the No-T compared to the T treatment in each of the timeframes analyzed, although the variability experienced in the No-T management becomes narrower with time. This finding is consistent with the results reported in Bhari et al. (2019) [3], who predicted higher yield instability, and, at the same time, higher yield increase in wheat systems cultivated with CA practices than the ones with $\mathrm{T}$, which presented more stability of yields, but a yield decrease over time.

This lower yield variability in the $T$ management may be explained by the fact that $\mathrm{T}$ is mainly implemented to increase and stabilize crop productivity by homogenizing the agroecosystem. T breaks up the soil surface and makes uniform the soil substrates to which it is applied, while fields under No-T practices are smoothed and compacted by the weather conditions [72]. In this sense, the T management may act as a buffer to the weather variability and produce more stable yields. Consequently, these results show how the two soil-management techniques respond differently under the same pedological and meteorological conditions.

Results of the simulations evidenced an increase of about $0.20 \%$ year $^{-1}$ in the evolution of SOC in the first $30 \mathrm{~cm}$ and $3.5 \%$ year $^{-1}$ of $\mathrm{N}$ uptake in the durum wheat cultivated with No-T. On the other hand, the T management would cause a decrease of $1.33 \%$ year of $^{-1}$ SOC and lower $\mathrm{N}$ uptake of $1.6 \%$ year $^{-1}$ for the $2020-2100$ period. This result agrees with the outcome of Valkama et al. (2020) [28], whose authors calibrated and validated ARMOSA with SOC measurements in three different sites (i.e., South of Finland, South of Kazakhstan, and North of Italy) that were cultivated with conventional and CA principles. The authors highlighted a decline of SOC in T systems (with an annual range between $1.17-0.6 \%$ year $^{-1}$ ) whereas the SOC slightly increased in No-T treatment $\left(0.35-0.45 \%\right.$ year $\left.^{-1}\right)$ in field crop systems in the three experimental sites. In addition, the authors pointed out the significant role of cover-crop-based farming systems in SOC storage, which will increase it with an annual sequestration rate of $0.71-0.95 \%$ year $^{-1}$.

Moreover, the effects of intensive soil $\mathrm{T}$ on the $\mathrm{N}$ cycling and $\mathrm{N}$ losses through leaching, which may lead to a higher $\mathrm{N}$ stress index in wheat-cropping systems, have been reported in several studies carried on future climate periods [3,4].

The improved water use efficiency of field crops under CA, which can be reflected in a higher water-stress index, has been observed previously in the Mediterranean climate $[3,19,73]$.

Therefore, the $\mathrm{T}$ system is not a sustainable management system, judging by the evolution of the SOC content and $\mathrm{N}$ leaching in the future period, while on the other hand, using the No-T management will enhance the SOC accumulation and prevent $\mathrm{N}$ losses. In this way, the No-T system with residues on the soil in durum wheat will constitute a proper management method to lower the $\mathrm{N}$ leaching and to enhance the content of SOC. These characteristics enhance to sequestrate atmospheric $\mathrm{CO}_{2}$ emissions, improve soil fertility, and soil water-holding capacity, and thus, as observed previously, will increase crop yield $[7,28,59]$

Consequently, cropping systems with enhanced soils characteristics derived from No-T management are more resilient to the effects of climate change, as reflected by the results of this study.

\section{Conclusions}

The ARMOSA model was effectively calibrated for the durum-wheat crop system grown under tillage and no-tillage techniques in the Campania region, using SWC data, LAI, and AGB measurements. Estimation errors were small, with RRMSE averaging 10.67\% for SWC at different depths, $26 \%$ for LAI, and $16 \%$ for AGB simulations. In addition, the model was further applied for the T and No-T management methods using the RCP4.5 and RCP8.5 climate-change scenarios. These simulations depicted the importance of implementing No-T management in durum-wheat cultivation to counteract climate change. The No-T will maintain higher yields than the T technique, will preserve and improve SOC along the years, and enhance the $\mathrm{N}$ uptake, thus diminishing $\mathrm{N}$ leaching. 
Therefore, these results suggest the appropriateness of ARMOSA model to quantify the effects of different soil-management techniques on soil-crop related variables of durum wheat system under current and future climate.

Further studies are suggested to include the three principles of CA in the model simulations-for instance, diverse crop sequences and associations, permanent soil cover, and minimum soil disturbance. The potential role of adopting simultaneously these principles is crucial to achieve $\mathrm{C}$ sequestration, and to improve soil moisture and nutrient availability, among other matters.

However, the most suitable soil-management techniques are site-specific to achieve more benefits. In this sense, simulation models such as ARMOSA are important instruments to assist decision-making in a certain context to assess the effectiveness of soil-management techniques prior to their implementation, also in the view of future climate change.

Author Contributions: Planning of the field experimental protocol, A.B. (Angelo Basile), A.T. (Antonio Troccoli) and R.D.M.; field data acquisition, A.T. (Anna Tedeschi), R.D.M., A.T. (Antonio Troccoli), M.R. and A.B. (Angelo Basile); laboratory analysis, N.O., A.T. (Antonio Troccoli) and M.R.; model simulation, À.P.-S., M.B. (Marco Botta) and M.B. (Marialaura Bancheri); data interpretation, À.P.-S., A.P., M.A., M.B. (Marialaura Bancheri), A.B. (Antonello Bonfante) and A.B. (Angelo Basile); manuscript writing, À.P.-S.; manuscript review, À.P.-S., A.P., M.A., A.B. (Antonello Bonfante) and A.B. (Angelo Basile). All authors have read and agreed to the published version of the manuscript.

Funding: This research was funded by POR Campania FESR 2007-2013, Asse 2, Ob. Operativo 2.1. Ricerca sperimentale per la realizzazione di CAMPUS dell'Innovazione for the QUARC projectQualità delle produzioni tipiche Campane ed il suo territorio: approcci innovativi ed integrati per rafforzare la competitività del sistema agroalimentare- with the grant number Decreto Dirigenziale ${ }^{\circ}$ 327 of 11th August 2009; and by the European Commission Horizon 2020, LANDSUPPORT project, grant number 774234 .

Institutional Review Board Statement: Not applicable.

Informed Consent Statement: Not applicable.

Data Availability Statement: The data that support the findings of this study are available from the corresponding author upon request.

Conflicts of Interest: The authors declare no conflict of interest. The funders had no role in the design of the study; in the collection, analyses, or interpretation of data; in the writing of the manuscript; or in the decision to publish the results.

\section{References}

1. Kassam, A.; Friedrich, T.; Derpsch, R. Global Spread of Conservation Agriculture Global Spread of Conservation Agriculture. Int. J. Environ. Stud. 2019, 76, 29-51. [CrossRef]

2. FAO Conservation Agriculture. Available online: https://www.fao.org/conservation-agriculture/en/ (accessed on 15 October 2021).

3. Bahri, H.; Annabi, M.; Cheikh, H.; Hamed, M.; Frija, A. Science of the Total Environment Assessing the Long-Term Impact of Conservation Agriculture on Wheat-Based Systems in Tunisia Using APSIM Simulations under a Climate Change Context. Sci. Total Environ. 2019, 692, 1223-1233. [CrossRef] [PubMed]

4. Devkota, K.P.; Hoogenboom, G.; Boote, K.J.; Singh, U.; Lamers, J.P.A.; Devkota, M.; Vlek, P.L.G. Agricultural and Forest Meteorology Simulating the Impact of Water Saving Irrigation and Conservation Agriculture Practices for Rice-Wheat Systems in the Irrigated Semi-Arid Drylands of Central Asia. Agric. For. Meteorol. 2015, 214-215, 266-280. [CrossRef]

5. Laudicina, V.A.; Novara, A.; Gristina, L.; Badalucco, L. Soil Carbon Dynamics as Affected by Long-Term Contrasting Cropping Systems and Tillages under Semiarid Mediterranean Climate. Appl. Soil Ecol. 2014, 73, 140-147. [CrossRef]

6. Liu, S.; Yang, J.Y.; Zhang, X.Y.; Drury, C.F.; Reynolds, W.D.; Hoogenboom, G. Modelling Crop Yield, Soil Water Content and Soil Temperature for a Soybean-Maize Rotation under Conventional and Conservation Tillage Systems in Northeast China. Agric. Water Manag. 2013, 123, 32-44. [CrossRef]

7. Perego, A.; Rocca, A.; Cattivelli, V.; Tabaglio, V.; Fiorii, A.; Barbieri, S.; Schillaci, C.; Chiodini, M.E.; Brenna, S.; Acutis, M. Agro-Environmental Aspects of Conservation Agriculture Compared to Conventional Systems: A 3-Year Experience on 20 Farms in the Po Valley. Agric. Syst. 2019, 168, 73-87. [CrossRef]

8. Colecchia, S.A.; De Vita, P.; Rinaldi, M. Effects of Tillage Systems in Durum Wheat under Rainfed Mediterranean Conditions. Cereal Res. Commun. 2015, 43, 704-716. [CrossRef] 
9. Troccoli, A.; Maddaluno, C.; Mucci, M.; Russo, M.; Rinaldi, M. Is It Appropriate to Support the Farmers for Adopting Conservation Agriculture? Economic and Environmental Impact Assessment. Ital. J. Agron. 2015, 10, 169-177. [CrossRef]

10. ISTAT. Data Warehouse of Statistics Produced by ISTAT-Italian National Institute of Statistics. 2012. Available online: http: / / dati.istat.it/Index.aspx (accessed on 20 September 2021).

11. Marandola, D.; Belliggiano, A.; Romagnoli, L.; Ievoli, C. The Spread of No-till in Conservation Agriculture Systems in Italy: Indications for Rural Development Policy-Making. Agric. Food Econ. 2019, 7, 7. [CrossRef]

12. European Commission. List of Potential Agricultural Practices That Eco-Schemes Could Support; European Commission: Brussels, Belgium, 2021; p. 5.

13. Italmopa-Associazione Industriali Mugnai d'Italia. Available online: https://www.italmopa.com/landamento-economico-delsettore/ (accessed on 20 September 2021).

14. International Grain Council. Available online: https://www.igc.int/en/default.aspx (accessed on 20 September 2021).

15. Abd-Elmabod, S.K.; Muñoz-Rojas, M.; Jordán, A.; Anaya-Romero, M.; Phillips, J.D.; Laurence, J.; Zhang, Z.; Pereira, P.; Fleskens, L.; van der Ploeg, M.; et al. Climate Change Impacts on Agricultural Suitability and Yield Reduction in a Mediterranean Region. Geoderma 2020, 374, 114453. [CrossRef]

16. Bird, D.N.; Benabdallah, S.; Gouda, N.; Hummel, F.; Koeberl, J.; La Jeunesse, I.; Meyer, S.; Prettenthaler, F.; Soddu, A.; WoessGallasch, S. Modelling Climate Change Impacts on and Adaptation Strategies for Agriculture in Sardinia and Tunisia Using AquaCrop and Value-at-Risk. Sci. Total Environ. 2016, 543, 1019-1027. [CrossRef] [PubMed]

17. IPCC. Part A: Global and Sectoral Aspects. (Contribution of Working Group II to the Fifth Assessment Report of the Intergovernmental Panel on Climate Change). In Climate Change 2014: Impacts, Adaptation and Vulnerability; IPCC: Geneva, Switzerland, 2014; p. 1132.

18. Ahmed, M.; Nasib, M.; Asim, M.; Aslam, M.; Hassan, F.; Higgins, S.; Stöckle, C.O.; Hoogenboom, G. Calibration and Validation of APSIM-Wheat and CERES-Wheat for Spring Wheat under Rainfed Conditions: Models Evaluation and Application. Comput. Electron. Agric. 2016, 123, 384-401. [CrossRef]

19. Ngwira, A.R.; Aune, J.B.; Thierfelder, C. DSSAT Modelling of Conservation Agriculture Maize Response to Climate Change in Malawi. Soil Tillage Res. 2014, 143, 85-94. [CrossRef]

20. Corbeels, M.; Berre, D.; Rusinamhodzi, L.; Lopez-Ridaura, S. Can We Use Crop Modelling for Identifying Climate Change Adaptation Options? Agric. For. Meteorol. 2018, 256-257, 46-52. [CrossRef]

21. Shafeeq, M.P.; Aggarwal, P.; Krishnan, P. Modeling the Temporal Distribution of Water, Ammonium-N and Nitrate-N in the Root Zone of Wheat Using HYDRUS-2D under Conservation Agriculture. Environ. Sci. Pollut. Res. 2020, 27, 2197-2216. [CrossRef]

22. Corbeels, M.; Chirat, G.; Messad, S.; Thierfelder, C. Performance and Sensitivity of the DSSAT Crop Growth Model in Simulating Maize Yield under Conservation Agriculture. Eur. J. Agron. 2016, 76, 41-53. [CrossRef]

23. Gerardeaux, E.; Giner, M.; Ramanantsoanirina, A.; Dusserre, J. Positive Effects of Climate Change on Rice in Madagascar. Agron. Sustain. Dev. 2012, 32, 619-627. [CrossRef]

24. Maccarthy, D.S.; Vlek, P.L.G.; Bationo, A.; Tabo, R.; Fosu, M. Field Crops Research Modeling Nutrient and Water Productivity of Sorghum in Smallholder Farming Systems in a Semi-Arid Region of Ghana. Field Crop. Res. 2010, 118, 251-258. [CrossRef]

25. Chaki, A.K.; Gaydon, D.S.; Dalal, R.C.; Bellotti, W.D.; Gathala, M.K.; Hossain, A.; Menzies, N.W. How We Used APSIM to Simulate Conservation Agriculture Practices in the Rice-Wheat System of the Eastern Gangetic Plains. Field Crop. Res. 2022, 275, 108344. [CrossRef]

26. Matthews, R.B.; Rivington, M.; Muhammed, S.; Newton, A.C.; Hallett, P.D. Adapting Crops and Cropping Systems to Future Climates to Ensure Food Security: The Role of Crop Modelling. Glob. Food Sec. 2013, 2, 24-28. [CrossRef]

27. Perego, A.; Giussani, A.; Sanna, M.; Fumagalli, M.; Carozzi, M.; Brenna, S.; Acutis, M. The ARMOSA Simulation Crop Model: Overall Features, Calibration and Validation Results. Ital. J. Agrometeorol. 2013, 18, 23-38.

28. Valkama, E.; Kunypiyaeva, G.; Zhapayev, R.; Karabayev, M.; Zhusupbekov, E.; Perego, A.; Schillaci, C.; Sacco, D.; Moretti, B.; Grignani, C.; et al. Can Conservation Agriculture Increase Soil Carbon Sequestration? A Modelling Approach. Geoderma 2020, 369, 114298. [CrossRef]

29. Hargreaves, G.H. The estimation of potential and crop evapotranspiration. Am. Soc. Agric. Eng. Trans. 1974, 17, 701-704. [CrossRef]

30. MIPAF-Ministero delle Politiche Agricole e Forestali. Metodi Ufficiali di Analisi Chimica del Suolo; MIPAF: Rome, Italy, 1999; pp. 1-63.

31. Reynolds, W.D.; Elrick, D.E. Constant head well permeameter (vadose zone). In Methods of Soil Analysis. Part 4. Physical Methods Dane, J., Topp, G.C., Eds.; Soil Science Society of America: Madison, WI, USA, 2002.

32. Arya, L.M. Wind and hot air methods. In Methods of Soil Analysis. Part 4. Physical Methods; SSSA Book Series; Dane, J.K., Topp, G.C., Eds.; Soil Science Society of America: Madison, WI, USA, 2002; Volume 5, pp. 916-920.

33. Basile, A.; Buttafuoco, G.; Mele, G.; Tedeschi, A. Complementary Techniques to Assess Physical Properties of a Fine Soil Irrigated with Saline Water. Environ. Earth Sci. 2012, 66, 1797-1807. [CrossRef]

34. Van Genuchten, M.T. A closed-form equation for predicting the hydraulic conductivity of unsaturated soils. Soil Sci. Soc. Am. J. 1980, 44, 892-898. [CrossRef]

35. Witzenberger, A.; Hack, H.; van den Boom, T. Erläuterungen zum BBCH-Dezimal-Code für die Entwicklungsstadien des Getreides-Mit Abbildungen. Gesunde Pflanz. 1989, 41, 384-388. 
36. Rockel, B.; Will, A.; Hense, A. The Regional Climate Model COSMO-CLM (CCLM). Meteorol. Z. 2008, 17, 347-348. [CrossRef]

37. Bucchignani, E.; Montesarchio, M.; Zollo, A.L.; Mercogliano, P. High-Resolution Climate Simulations with COSMO-CLM over Italy: Performance Evaluation and Climate Projections for the 21st Century. Int. J. Climatol. 2016, 36, 735-756. [CrossRef]

38. Zollo, A.L.; Rillo, V.; Bucchignani, E.; Montesarchio, M.; Mercogliano, P. Extreme Temperature and Precipitation Events over Italy: Assessment of High-Resolution Simulations with COSMO-CLM and Future Scenarios. Int. J. Climatol. 2016, 36, 987-1004. [CrossRef]

39. Meinshausen, M.; Smith, S.J.; Calvin, K.; Daniel, J.S.; Kainuma, M.L.T.; Lamarque, J.; Matsumoto, K.; Montzka, S.A.; Raper, S.C.B.; Riahi, K.; et al. The RCP Greenhouse Gas Concentrations and Their Extensions from 1765 to 2300. Clim. Chang. 2011, 109, $213-241$. [CrossRef]

40. Scoccimarro, E.; Gualdi, S.; Bellucci, A.; Sanna, A.; Fogli, P.G.; Manzini, E.; Vichi, M.; Oddo, P.; Navarra, A. Effects of Tropical Cyclones on Ocean Heat Transport in a High-Resolution Coupled General Circulation Model. J. Clim. 2011, 24, $4368-4384$. [CrossRef]

41. Donatelli, M.; Bellocchi, G.; Fontana, F. RadEst3.00: Software to Estimate Daily Radiation Data from Commonly Available Meteorological Variables. Eur. J. Agron. 2003, 18, 363-367. [CrossRef]

42. De Wit, A.; Boogaard, H.; Fumagalli, D.; Janssen, S.; Knapen, R.; van Kraalingen, D.; Supit, I.; van der Wijngaart, R.; van Diepen, K. 25 Years of the WOFOST Cropping Systems Model. Agric. Syst. 2019, 168, 154-167. [CrossRef]

43. Groenendijk, P.; Heinen, M.; Klammler, G.; Fank, J.; Kupfersberger, H.; Pisinaras, V.; Gemitzi, A.; Peña-Haro, S.; García-Prats, A.; Pulido-Velazquez, M.; et al. Performance Assessment of Nitrate Leaching Models for Highly Vulnerable Soils Used in Low-Input Farming Based on Lysimeter Data. Sci. Total Environ. 2014, 499, 463-480. [CrossRef]

44. Pirttioja, N.; Carter, T.R.; Fronzek, S.; Bindi, M.; Hoffmann, H. Temperature and Precipitation Effects on Wheat Yield across a European Transect: A Crop Model Ensemble Analysis Using Impact Response Surfaces. Clim. Res. 2015, 65, 87-105. [CrossRef]

45. Sándor, R.; Barcza, Z.; Acutis, M.; Doro, L.; Hidy, D.; Köchy, M.; Minet, J.; Lellei-Kovács, E.; Ma, S.; Perego, A.; et al. Multi-Model Simulation of Soil Temperature, Soil Water Content and Biomass in Euro-Mediterranean Grasslands: Uncertainties and Ensemble Performance. Eur. J. Agron. 2017, 88, 22-40. [CrossRef]

46. Thornley, J.H.M.; Johnson, I.R. Plant and Crop Modelling: A Mathematical Approach to Plant and Crop Physiology; Clarendon: Oxford, UK, 1990.

47. Johnsson, H.; Bergstrom, L.; Jansson, P.E.; Paustian, K. Simulated Nitrogen Dynamics and Losses in a Layered Agricultural Soil. Agric. Ecosyst. Environ. 1987, 18, 333-356. [CrossRef]

48. Parton, W.J. Predicting soil temperatures in a shortgrass steppe. Soil Sci. 1984, 138, 93-101. [CrossRef]

49. Neitsch, S.; Arnold, J.; Kiniry, J.; Williams, J. Soil Water Assess. Tool; Theoretical Documentation Version 2009; Texas Water Resources Institute: College Station, TX, USA, 2011.

50. Pereira, L.S.; Paredes, P.; Rodrigues, G.C.; Neves, M. Modeling Malt Barley Water Use and Evapotranspiration Partitioning in Two Contrasting Rainfall Years. Assessing AquaCrop and SIMDualKc Models. Agric. Water Manag. 2015, 159, 239-254. [CrossRef]

51. Wessolek, G.; Plagge, R.; Leij, F.J.; van Genuchten, M.T. Analysing Problems in Describing Field and Laboratory Measured Soil Hydraulic Properties. Geoderma 1994, 64, 93-110. [CrossRef]

52. Basile, A.; Ciollaro, G.; Coppola, A. Hysteresis in Soil Water Characteristics as a Key to Interpreting Comparisons of Laboratory and Field Measured Hydraulic Properties. Water Resour. Res. 2003, 39, 1355. [CrossRef]

53. Basile, A.; Coppola, A.; De Mascellis, R.; Randazzo, L. Scaling Approach to Deduce Field Unsaturated Hydraulic Properties and Behavior from Laboratory Measurements on Small Cores. Vadose Zone J. 2006, 5, 1005-1016. [CrossRef]

54. Sanna, M.; Bellocchi, G.; Fumagalli, M.; Acutis, M. A New Method for Analysing the Interrelationship between Performance Indicators with an Application to Agrometeorological Models. Environ. Model. Softw. 2015, 73, 286-304. [CrossRef]

55. Addiscott, T.M.; Whitmore, A.P. Computer Simulation of Changes in Soil Mineral Nitrogen and Crop Nitrogen during Autumn, Winter and Spring. J. Agric. Sci. 1987, 109, 141-157. [CrossRef]

56. Loague, K.; Green, R.E. Statistical and Graphical Methods for Evaluating Solute Transport Models: Overview and Application. J. Contam. Hydrol. 1991, 7, 51-73. [CrossRef]

57. Gupta, V.H.; Sorooshian, S.; Yapo, P.O. Status of automatic calibration for hydrologic models: Comparison with multilevel expert calibration. J. Hydrol. Eng. 1999, 4, 135-143. [CrossRef]

58. Nash, J.E.; Sutcliffe, J.V. River flow forecasting through conceptual models: Part 1. A discussion of principles. J. Hydrol. 1970, 10, 282-290. [CrossRef]

59. Perego, A.; Sanna, M.; Giussani, A.; Chiodini, M.E.; Fumagalli, M.; Pilu, S.R.; Bindi, M.; Moriondo, M.; Acutis, M. Designing a High-Yielding Maize Ideotype for a Changing Climate in Lombardy Plain (Northern Italy). Sci. Total Environ. 2014, 499, 497-509. [CrossRef]

60. Levene, H. Robust tests for equality of variances. In Contributions to Probability and Statistics: Essays in Honor of Harold Hotelling; Olkin, I., Hotelling, H., Eds.; Stanford University Press: Palo Alto, CA, USA, 1960; pp. 278-292.

61. Acutis, M.; Scaglia, B.; Confalonieri, R. Perfunctory Analysis of Variance in Agronomy, and Its Consequences in Experimental Results Interpretation. Eur. J. Agron. 2012, 43, 129-135. [CrossRef]

62. IUSS Working Group WRB. World Reference Base for Soil Resources 2014. International Soil Classification System for Naming Soils and Creating Legends for Soil Maps; Update 2015; FAO: Rome, Italy, 2015. 
63. Bonfante, A.; Basile, A.; Acutis, M.; De Mascellis, R.; Manna, P.; Perego, A.; Terribile, F. SWAP, CropSyst and MACRO Comparison in Two Contrasting Soils Cropped with Maize in Northern Italy. Agric. Water Manag. 2010, 97, 1051-1062. [CrossRef]

64. Bechini, L.; Bocchi, S.; Maggiore, T.; Confalonieri, R. Parameterization of a Crop Growth and Development Simulation Model at Sub-Model Components Level. An Example for Winter Wheat (Triticum Aestivum L.). Environ. Model. Softw. 2006, 21, 1042-1054. [CrossRef]

65. Stöckle, C.O.; Donatelli, M.; Nelson, R. CropSyst, a Cropping Systems Simulation Model. Eur. J. Agron. 2003, 18, 289-307. [CrossRef]

66. Keating, B.A.; Carberry, P.S.; Hammer, G.L.; Probert, M.E.; Robertson, M.J.; Holzworth, D.; Huth, N.I.; Hargreaves, J.N.G.; Meinke, H.; Hochman, Z.; et al. An Overview of APSIM, a Model Designed for Farming Systems Simulation. Eur. J. Agron. 2003, 18, 267-288. [CrossRef]

67. Jones, J.W.; Hoogenboom, G.; Porter, C.H.; Boote, K.J.; Batchelor, W.D.; Hunt, L.A.; Wilkens, P.W.; Singh, U.; Gijsman, A.J.; Ritchie, J.T. The DSSAT Cropping System Model. Eur. J. Agron. 2003, 18, 235-265. [CrossRef]

68. Beckie, H.J.; Flower, K.C.; Ashworth, B. Farming without Glyphosate? Plants 2020, 9, 96. [CrossRef] [PubMed]

69. Bonfante, A.; Monaco, E.; Langella, G.; Mercogliano, P.; Bucchignani, E.; Manna, P.; Terribile, F. A Dynamic Viticultural Zoning to Explore the Resilience of Terroir Concept under Climate Change. Sci. Total Environ. 2018, 624, 294-308. [CrossRef]

70. Asseng, S. Rising Temperatures Reduce Global Wheat Production. Nat. Clim. Chang. 2015, 5, 143-147. [CrossRef]

71. Kuhn, N.J.; Hu, Y.; Bloemertz, L.; He, J.; Li, H.; Greenwood, P. Conservation Tillage and Sustainable Intensification of Agriculture: Regional vs. Global Benefit Analysis. Agric. Ecosyst. Environ. 2016, 216, 155-165. [CrossRef]

72. O'Brien, P.L.; Daigh, A.L.M. Tillage Practices Alter the Surface Energy Balance-A Review. Soil Tillage Res. 2019, 195, 104354. [CrossRef]

73. Lampurlanés, J.; Plaza-Bonilla, D.; Álvaro-Fuentes, J.; Cantero-Martínez, C. Long-Term Analysis of Soil Water Conservation and Crop Yield under Different Tillage Systems in Mediterranean Rainfed Conditions. Field Crop. Res. 2016, 189, 59-67. [CrossRef] 